\title{
14-3-3 $\varepsilon$ and $\zeta$ Regulate Neurogenesis and Differentiation of Neuronal Progenitor Cells in the Developing Brain
}

\author{
Kazuhito Toyo-oka, ${ }^{1,2}$ Tomoka Wachi, ${ }^{1,2}$ Robert F. Hunt, ${ }^{3}$ Scott C. Baraban, ${ }^{3}$ Shinichiro Taya, ${ }^{4}$ Hayley Ramshaw, ${ }^{5}$ \\ Kozo Kaibuchi, ${ }^{4}$ Quenten P. Schwarz, ${ }^{5}$ Angel F. Lopez, ${ }^{5}$ and Anthony Wynshaw-Boris ${ }^{1,6}$ \\ ${ }^{1}$ Department of Pediatrics and Institute for Human Genetics, University of California, San Francisco School of Medicine, San Francisco, California 94143 , \\ 2Department of Neurobiology and Anatomy, Drexel University College of Medicine, Philadelphia, Pennsylvania 19129, ${ }^{3}$ Epilepsy Research Laboratory, \\ Department of Neurological Surgery, University of California, San Francisco, San Francisco, California 94143, ${ }^{4}$ Department of Cell Pharmacology, Nagoya \\ University Graduate School of Medicine, Nagoya, Aichi 466 - 8550, Japan, ${ }^{5}$ Department of Human Immunology, Centre for Cancer Biology, South Australia \\ Pathology, Adelaide, South Australia, Australia, and 'Department of Genetics and Genome Sciences, Case Western Reserve University School of Medicine, \\ Cleveland, Ohio 44106
}

During brain development, neural progenitor cells proliferate and differentiate into neural precursors. These neural precursors migrate along the radial glial processes and localize at their final destination in the cortex. Numerous reports have revealed that 14-3-3 proteins are involved in many neuronal activities, although their functions in neurogenesis remain unclear. Here, using $14-3-3 \boldsymbol{\varepsilon} / \zeta$ double knockout mice, we found that 14-3-3 proteins are important for proliferation and differentiation of neural progenitor cells in the cortex, resulting in neuronal migration defects and seizures. 14-3-3 deficiency resulted in the increase of $\delta$-catenin and the decrease of $\beta$-catenin and $\alpha \mathrm{N}$-catenin. 14-3-3 proteins regulated neuronal differentiation into neurons via direct interactions with phosphorylated $\delta$-catenin to promote F-actin formation through a catenin/Rho GTPase/Limk1/cofilin signaling pathway. Conversely, neuronal migration defects seen in the double knock-out mice were restored by phosphomimic Ndell mutants, but not $\delta$-catenin. Our findings provide new evidence that 14-3-3 proteins play important roles in neurogenesis and neuronal migration via the regulation of distinct signaling cascades.

Key words: 14-3-3; delta-catenin; neurogenesis; neuronal differentiation; neuronal migration

\section{Introduction}

14-3-3 proteins were initially identified as abundant proteins in the brain, and there are seven separate genes or isoforms coding for these proteins present in mammals (denoted by Greek letters: $\beta, \gamma, \varepsilon, \zeta, \eta, \tau, \delta)$ (Bridges and Moorhead, 2005). To date, 14-3-3

Received June 13, 2013; revised July 21, 2014; accepted July 25, 2014.

Author contributions: K.T., S.C.B., Q.P.S., A.F.L., and A.W.-B. designed research; K.T., T.W., R.F.H., H.R., and S.T. performed research; S.T. contributed unpublished reagents/analytic tools; K.T., K.K., and A.W.-B. analyzed data; K.T., Q.P.S., A.F.L., and A.W.-B. wrote the paper.

This work was supported by the National Alliance for Research on Schizophrenia and Depression Young Investigator Award to K.T., the National Institutes of Health (NSO41310, HD047380, and NS073159 to A.W.-B.; NSO40272 to S.C.B.), and the National Institutes of Health fellowship (NS085046 to R.F.H.). We thank Dr. Franck Polleux (The Scripps Research Institute), Dr. Neal Copeland (National Institutes of Health), Dr. Junji Takeda and Dr. Kosuke Yusa (Osaka University, Japan), and Dr. Tong-Chuan He, Dr. Edward Yeh, and Dr. Haining Zhong for providing their plasmids; Dr. Robert Hevner (University of Washington) for providing anti-Tbr2 antibody; Dr. Louis Reichardt (University of California, San Francisco) for helpful criticism and comments on the manuscript; Gene Service Ltd for providing the BAC clones developed at the Wellcome Trust Sanger Institute; and the University of California, San Francisco, Sandler Center Lentiviral RNAi Core for producing the lentiviruses; The NCAT2 antibody developed by S. Hirano was obtained from the Developmental Studies Hybridoma Bank developed under the auspices of the National Institute of Child Health and Human Development and maintained by the University of lowa, Department of Biology, lowa City, lowa.

The authors declare no competing financial interests.

Correspondence should be addressed to either of the following: Dr. Anthony Wynshaw-Boris, Department of Genetics and Genome Sciences, Case Western Reserve University School of Medicine, 10900 Euclid Avenue, BRB731, Cleveland, 0H 44106. E-mail: ajw168@case.edu; or Dr. Kazuhito Toyo-oka, Department of Neurobiology and Anatomy, Drexel University College of Medicine, 2900 Queen Lane, Room 186, Philadelphia, PA 19129, E-mail: ktoyooka@drexelmed.edu.

DOI:10.1523/JNEUROSCI.2513-13.2014

Copyright $\odot 2014$ the authors $\quad 0270-6474 / 14 / 3412168-14 \$ 15.00 / 0$ proteins bind to $>100$ binding partners, and these interactions are mainly phosphoserine- or threonine-dependent (Chen et al., 2011; Gardino and Yaffe, 2011). These binding partners are involved in a wide range of cellular phenomena, including cell cycle regulation and apoptosis (Tzivion and Avruch, 2002; Gardino and Yaffe, 2011). Previous studies demonstrated that 14-3-3 proteins are involved in many types of neural processes, such as synaptic function and learning and memory (Broadie et al., 1997; Zhou et al., 1999). Also, there is some evidence that 14-3-3 proteins play a role in complex neuropsychiatric disorders. We recently found that the Ywhaz mutants, coding for 14-3-3 $\zeta$, display neuronal migration and behavioral defects related to schizophrenia (Cheah et al., 2011). Our association study revealed that the YWHAE (coding for 14-3-3e) is a novel susceptible gene for schizophrenia (Ikeda et al., 2008). Thus, the 14-3-3 proteins are multifunctional proteins involved in the variety of cellular and neuronal phenomena. It is important to elucidate the functions of the 14-3-3 proteins to understand the mechanisms of the cellular events important for brain functions.

During mouse brain development, the majority of projection neurons are generated from neural progenitor cells localized in the ventricular zone (VZ) (Kriegstein and Alvarez-Buylla, 2009). Radial glial cells (RGCs) divide symmetrically to produce two RGCs, or asymmetrically to generate a RGC and a neuron either directly or indirectly through intermediate progenitor cells (IPCs) (Pontious et al., 2008). After IPCs are generated from 
RGCs, IPCs migrate into the subventricular zone (SVZ) and usually divide once to generate two neurons. RGCs and IPCs regulate the proper number of neurons in the cortex through their proliferation and cell division. The balance of proliferation and differentiation of neuronal progenitor cells are crucial to generate a complex, functional brain. Although recent research has clarified some of the cellular mechanisms responsible for these processes, there are many gaps in our knowledge, and the precise mechanisms involved are poorly characterized.

To clarify potential mechanisms by which 14-3-3 proteins are important for neurogenesis, we focused our analysis on the functions of the $14-3-3 \varepsilon$ and $14-3-3 \zeta$ proteins in cortical development by using loss-of-function approaches in mice. We found that Ywhae and Ywhaz double mutant (dKO) mice showed severe seizures, and these proteins are important for proper proliferation of RGCs and IPCs and their differentiation into neurons. These 14-3-3 proteins bound to PKA-phosphorylated $\delta$-catenin and regulated F-actin formation by controlling the activity of the Rho family of GTPases and the phosphorylation status of Limk1 and cofilin. Finally, we discovered that the dKO mice display severe neuronal migration defects in the cortex, and these neuronal migration defects are restored by the Ndell proteins, but not the $\delta$-catenin proteins, demonstrating that distinct pathways result in neuronal migration and neurogenesis defects in 14-3-3 mutant mice.

\section{Materials and Methods}

Mice. The Ywhae and Ywhaz KO mice were generated as previously described (Toyo-oka et al., 2003; Cheah et al., 2011) and were maintained in the 129/SvEv background. The hGFAP-Cre transgenic mice and Gt(ROSA)26-reporter mice were maintained in 129/SvEv background (Soriano, 1999; Zhuo et al., 2001). Male and female mice were used. All animal experiments were performed under the protocols approved by the University of California San Francisco and Drexel University Animal Care and Use Committees and following guidelines of the National Institutes of Health.

Ywhae conditional KO mice production. We generated the ES cells with a conditional allele of the Ywhae gene coding for 14-3-3e using a previously described BAC recombineering technique (Warming et al., 2005). We injected targeted ES cells into 129/Ola blastocysts and obtained germline transmission. The original allele contained a PGK-neo gene surrounded by FRT sites. Homozygotes for this allele died at birth, similar to conventional Ywhae knock-outs. Therefore, we used the germline deleter FLP recombinase transgenic mouse (C57BL/6NTac-Tg(ACTBFlpe)2Arte, Taconic \#7089) to remove PGK-neo, producing the Ywhae flox allele. The resulting homozygous Ywhae flox/flox mouse was viable and phenotypically normal. We maintained floxed-conditional mice $\left(\right.$ Ywhae $^{+/ f l o x}$ ) by backcrossing them into 129/SvEv. Genotyping for these mice was performed by PCR by using their tail DNA. The tails were digested by agitation in digestion buffer (20 mM Tris, $\mathrm{pH} 8.0,0.45 \%$ NP-40, 0.45\% Tween 20) supplemented with $250 \mu \mathrm{g} / \mathrm{ml}$ Proteinase K (Sigma, P6556) overnight at $55^{\circ} \mathrm{C}$. After inactivating proteinase $\mathrm{K}$ for 15 $\mathrm{min}$ at $95^{\circ} \mathrm{C}$, the digested tails were centrifuged at $21,130 \times g$ for $15 \mathrm{~min}$; $0.5 \mu \mathrm{l}$ of supernatant was used for $10 \mu \mathrm{l}$ PCR, which was performed using the GoTaq Green Mix polymerase (Promega). The following primers were used: aggtaccaaaacagtaagccatctcccta (P1: 1433e_Int4_R1_KpnI) and gcatgtgtttgtctgtcagaggac (P2: 1433e_Seq_Int4). The size of the wildtype and floxed alleles' bands were $450 \mathrm{bp}$ and $536 \mathrm{bp}$, respectively (Fig. $1 B)$. To detect the $\mathrm{KO}$ allele, the following primers were used: aggtaccaaaacagtaagccatctcccta (P1: 1433e_Int4_R1_KpnI) and ttcttttgtagaaattggggaaggtcatgg (P3: 14epKO_F1). The size of the KO alleles' bands was 664 bp (Fig. 1C).

Antibodies. The following primary antibodies were used: $14-3-3 \varepsilon$ (sc-

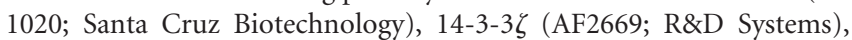
$\delta$-catenin (sc-81793; Santa Cruz Biotechnology and ab11352; Abcam), $\beta$-catenin (C-2206; Sigma), p120catenin (AM20014AF-N; Acris Anti- bodies), AlexaFluor-594-conjugated phalloidin (A12381; Invitrogen/ Molecular Probes), $\alpha \mathrm{N}$-catenin (NCAT2; Developmental Studies Hybridoma Bank), Phospho-Limk1 (Phospho-Thr508) (Y011126; abm), Limk1 (MAB10750; Millipore), Phospho-cofilin (Phospho-Ser3) (GTX12866; GeneTex), cofilin (GTX102156; GeneTex), Ctip2 (ab18465; Abcam), Brn-2 (sc-6029; Santa Cruz Biotechnology), HA (11583816001; Roche Diagnostics), FLAG (637301; BioLegend), His (G020; abm), GAPDH (ACR001P; Acris Antibodies), GFP/Venus (600-101-215; Rockland), BrdU (555627; BD Biosciences PharMingen), Ki67 (NCLKi67p; Novocastra Laboratories), Tbr2 (a kind gift from Dr. Hevner, University of Washington and AB15894: Millipore), Tuj1 (MMS-435P; Covance), Cre (MMS-106P; Covance), Cleaved Caspase-3 (\#9661; Cell Signaling Technology), cdc42 (sc-8401; Santa Cruz Biotechnology; and PA1-092X; Pierce), Rac1 (GTX100761; GeneTex; and sc-95; Santa Cruz Biotechnology), RhoA (sc-418; Santa Cruz Biotechnology; and sc-179; Santa Cruz Biotechnology), Sox2 (sc-17320; Santa Cruz Biotechnology), and NeuN (MAB377; Millipore). We previously produced and used mouse monoclonal Phospho-Ndel1 (available from MBL International; D183-3) and rabbit anti-Ndell antibodies (Toyo-Oka et al., 2005).

The following secondary antibodies were used: AlexaFluor-488conjugated donkey-anti-mouse IgG (1:200), AlexaFluor-647-conjugated donkey-anti-mouse IgG (1:400), FITC-conjugated donkey-anti-rabbit IgG (1:200), TRITC-conjugated donkey-anti-rabbit IgG (1:200), Cy5conjugated donkey-anti-rabbit IgG (1:400), AlexaFluor-488-conjugated goat-anti-rat IgG (1:200), Cy5-conjugated donkey-anti-rat IgG (1:300), AlexaFluor-488-conjugated donkey-anti-goat IgG (1:200), Cy5-conjugated donkey-anti-goat IgG (1:400). AlexaFluor-conjugated second antibodies were purchased from the Invitrogen, and others were from the Jackson ImmunoResearch Laboratories.

Plasmids and RNAi. Mouse Ctnnd2, Ywhae, and Ywhaz cDNAs were obtained by RT-PCR using mouse brain mRNA and cloned into pEGFP (Clontech/Takara) or pHAHA (Addgene plasmid 12517) plasmids (Luu et al., 2005). Mouse $\beta$-catenin (Ctnnb1) and $\alpha \mathrm{N}$-catenin (Ctnna2) cDNAs were purchased from Thermo Scientific and cloned into pEGFP. To produce FLAG-tagged $\delta$-catenin, 6xHis-tagged $14-3-3 \zeta$ plasmids, we performed nested-PCR and cloned the products into the pcDNA3.1 mammalian expression vector (Invitrogen). HA-tagged ubiquitin and EGFP-tagged PKA catalytic subunit cDNAs were obtained from Addgene (plasmids 45521 and 18712) (Kamitani et al., 1997; Zhong et al., 2009). We purified all plasmids by NucleoBond Xtra purification kit (Macherey-Nagel).

shRNA against mouse $\delta$-catenin was cloned into pSCV2-Venus plasmid (a kind gift from Dr. Polleux) (Hand and Polleux, 2011). The target sequences used were gcaactatgtcgacttcta (shRNA1), which is previously used (Arikkath et al., 2008) and gccacttaccacggaacta (shRNA2). Certified control siRNA (actaccgttgttataggtg) was used as a negative control (Invitrogen) (Hand and Polleux, 2011). Lentiviral-based siRNA plasmids were obtained from Applied Biological Materials (abm). The target sequences used were tcaggcattctggacccacaggattactc (397) and gcacttcagctcaattctaaacctgaagg (460). Scrambled siRNA vector was also obtained from the abm. That sequence is gggtgaactcacgtcagaa.

Neurosphere production and neurosphere differentiation. Neurospheres were prepared and maintained as described previously with slight modification (Engele and Bohn, 1992; Kitajima et al., 2005; Youn et al., 2009). Briefly, cerebral cortices were isolated from E15.5 embryos, and hippocampal hems were removed. The cortices were treated by $0.25 \%$ trypsin for $15 \mathrm{~min}$ at $37^{\circ} \mathrm{C}$, and trypsin inhibitor (Sigma) was added to inactivate the trypsin. After triturating using a fire-polished Pasteur pipette, cells were seeded in 24-wells plate with DMEM supplemented with $\mathrm{N}-2$ supplement, human recombinant epidermal growth factor (10 ng/ $\mathrm{ml})$, and basic fibroblast growth factor $(10 \mathrm{ng} / \mathrm{ml})\left(2 \times 10^{6}\right.$ per well, primary neurosphere). The primary neurospheres were treated by $0.025 \%$ trypsin, and then trypsin inhibitor was added. To produce secondary neurospheres, the cells were seeded in 6-well plates $\left(5 \times 10^{6}\right.$ per well). These secondary neurospheres were used for assays. For neural differentiation assays, cells were plated in a poly-D-lysine (BD Biosciences) and laminin (Invitrogen) coated 8-well chamber slide $\left(1 \times 10^{6}\right.$ per well, Falcon/BD Biosciences) in neurosphere media. After overnight of incubation at $37^{\circ} \mathrm{C}$, media were replaced with $\mathrm{N} 2 \mathrm{~B} 27$ media (1:1 mix- 

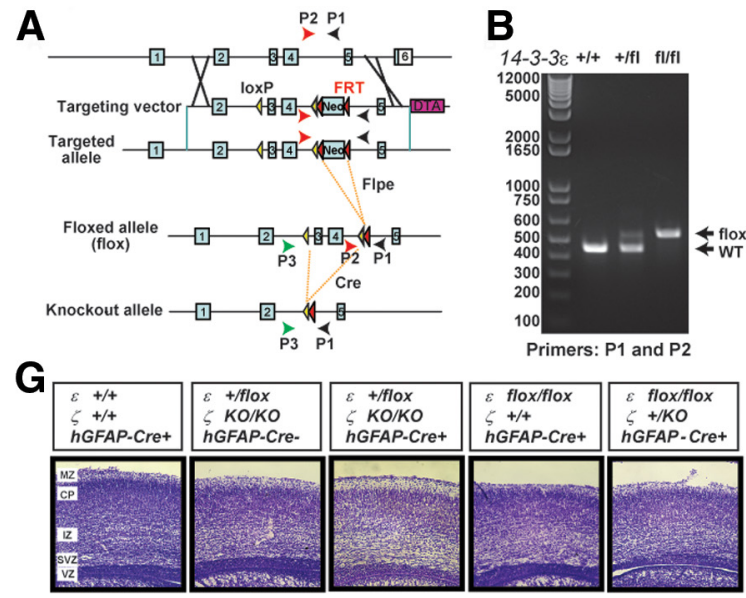

B
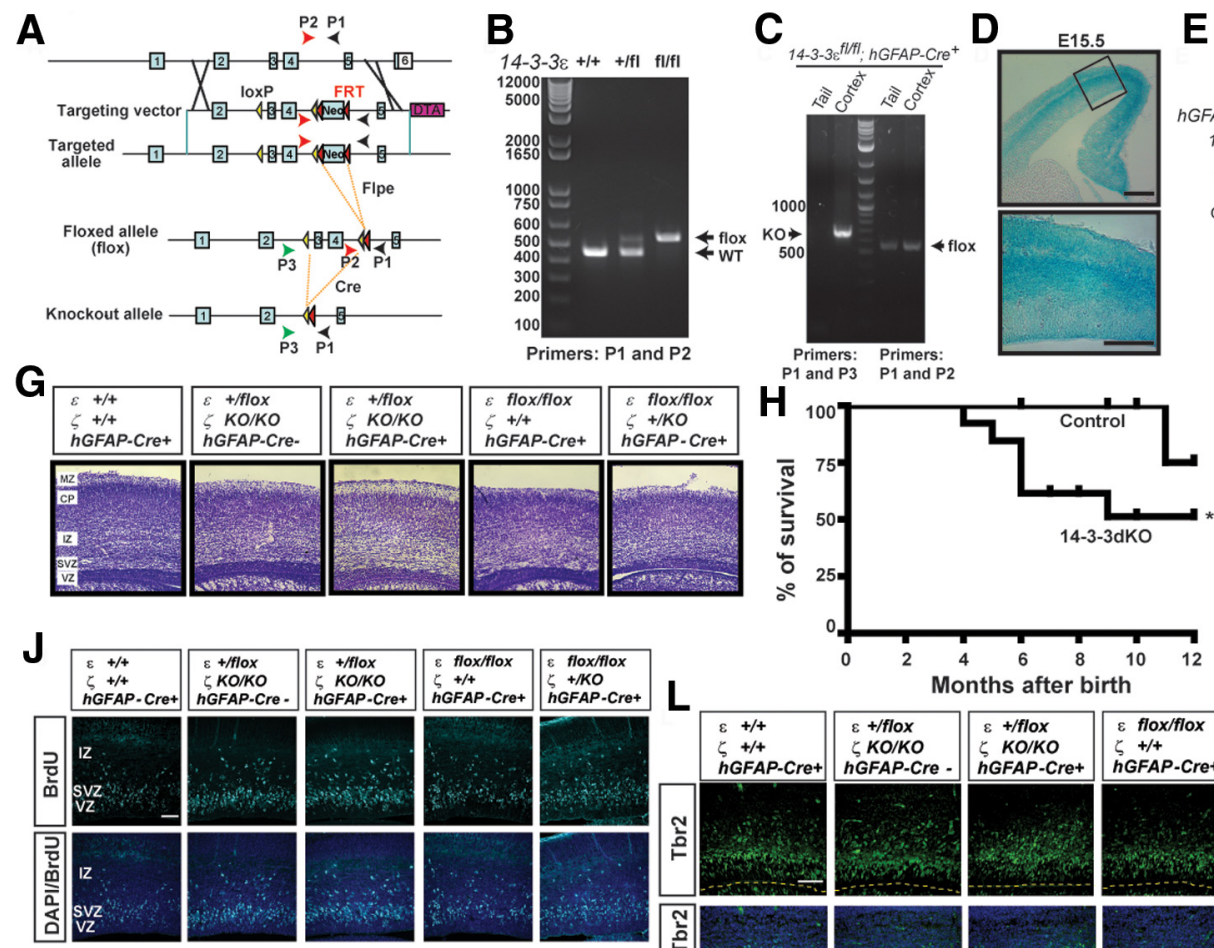

\section{K}

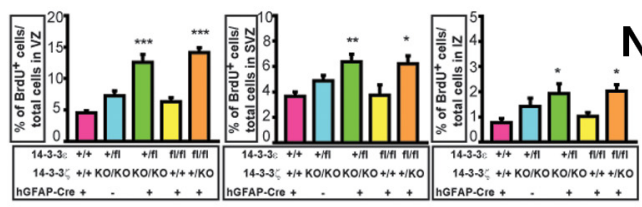

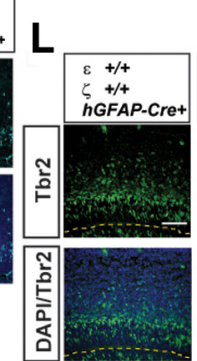

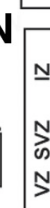

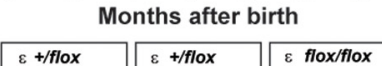

E

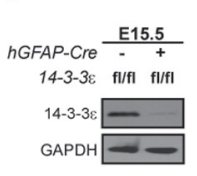

$\mathbf{F}$

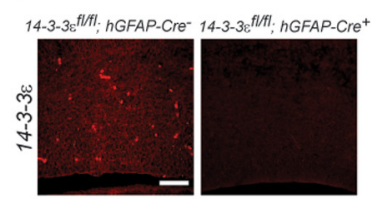

\section{I}
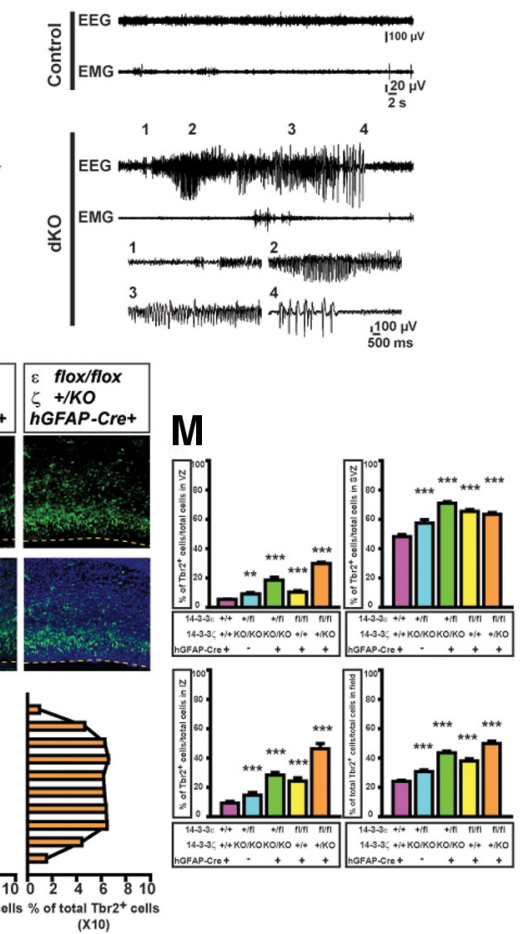

Figure 1. Loss of $Y$ whae and $Y$ whaz resulted in an increased number and an aberrant distribution of progenitor cells in the developing cerebral cortex. $\boldsymbol{A}$, Schematic illustration of the gene targeting of the $Y$ whae gene. Number indicates the exons of the $Y$ whae gene. Red and yellow arrowheads indicate FRT and loxP sites, respectively. P1, P2, and P3 indicate the primers used for genotyping. B, PCR genotyping of the conditional Ywhae knock-out mice. To detect the flox allele, P1 and P2 primers were used. Top and bottom bands represent the flox allele (536 bp) and the wild-type allele (450 bp), respectively. C, PCR genotyping of the $Y$ whae ${ }^{f / f l} ; h G F A P-C r e+$ mice (P15), which were produced by mating the conditional $Y$ whae KO mice with the $h$ GFAP-Cre mice. Primers $\mathrm{P} 1$ and $\mathrm{P} 3$ for the $\mathrm{K} 0$ allele and $\mathrm{P} 1$ and $\mathrm{P} 2$ for the flox allele were used. The size of the $\mathrm{K} 0$ allele's band is $664 \mathrm{bp}$. D. Cre recombinase was strongly expressed in the developing cortex, but not in all cells. Brain from the E15.5 embryo (ROSA26 ${ }^{+}$; $h$ GFAP-Cre $\left.{ }^{+}\right)$was stained by X-gal. Bottom, High-magnification view of the square region in the top panel. Scale bar, $100 \mu \mathrm{m} . \boldsymbol{E}$, Immunoblot analysis of

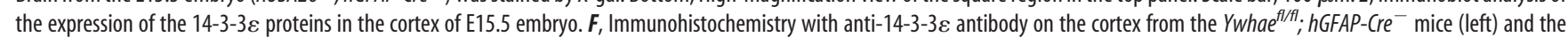
$Y_{\text {whae }}{ }^{f / f l} ;$ hGFAP-Cre (right) mice at E15.5. Scale bar, $100 \mu \mathrm{m}$. G, Nissl staining of the dKO mice at P21. MZ, Marginal zone. $\boldsymbol{H}$, Incidence of death in the control wild-type mice and the dKO mice. The control wild-type mice and the dKO mice were monitored over a period of 12 months. $n=10$ or 13 animals from the control wild-type mice or the dKO mice. ${ }^{*} p<0.05 . I, 14-3-3$ deficiency resulted in severe spontaneous seizures. Example EEG and corresponding EMG from a control and a dKO mouse during a typical electrographic seizure. The same EEG recording is expanded to show high resolution at four different stages of seizure progression (as noted by 1-4).J, In vivo BrdU proliferation assay reveals an increased number of progenitor cells in the dK0 embryos at E15.5. Scale bar, $50 \mu \mathrm{m} . K$, Quantification of BrdU ${ }^{+}$progenitor cells at E15.5. ${ }^{*} p<0.05 .{ }^{* *} p<0.01 .{ }^{* * *} p<0.001 . n=9-14$ areas from three to five animals per genotype. $L$, Immunohistochemistry with anti-Tbr2 antibody on the dKO mice. Dotted lines indicate the ventricular surface of the cortex. Scale bar, $100 \mu \mathrm{m}$. $M$, Quantification of the Tbr2 ${ }^{+} \mathrm{IPCs}$ in the VZ, SVZ, and IZ. ${ }^{* *} p<0.01$. ${ }^{* * *} p<$ 0.001. $n=5$ areas from three or four animals per genotype. $\boldsymbol{N}$, Distribution of the Tbr2 ${ }^{+} \mathrm{IPCs}$ through the cortex. Data are represented as the mean. $n=5$ areas from three or four animals per genotype.

ture of DMEM/F-12 media supplemented with N-2 and neurobasal media supplemented with B-27 supplements (Invitrogen), to allow cells to differentiate into neurons as described previously (Ying and Smith, 2003). For rescue experiments, dissociated cells were transfected by Lipofectamine LTX and PLUS Reagent (Invitrogen).

Histology and immunohistochemistry. Embryos were dissected and fixed with $4 \%$ PFA in PBS overnight at $4^{\circ} \mathrm{C}$. We saturated the fixed brains with $25 \%$ sucrose in PBS overnight at $4^{\circ} \mathrm{C}$ and cut them into $60 \mu \mathrm{m}$ sections for Nissl staining and $15 \mu \mathrm{m}$ sections for immunohistochemistry by cryostat after embedding them in optimal cutting temperature (Tissue-Tek) compound. Nissl staining was performed as previously described (Toyo-oka et al., 2003). For immunohistochemistry, we incubated sections in TBS with 3\% BSA, 1.5\% normal second antibody's host serum, and $0.15 \%$ Tween 20 (blocking buffer) for $20 \mathrm{~min}$ at room temperature. After an overnight incubation at $4^{\circ} \mathrm{C}$ by the primary antibody, we incubated sections with $3 \mu \mathrm{g} / \mathrm{ml}$ of fluorescent-tagged secondary antibody (Jackson ImmunoResearch Laboratories) in blocking buffer for $1 \mathrm{~h}$ at room temperature, and the sections were stained by DAPI ( $300 \mathrm{~nm}$, Invitrogen) at room temperature. Sections were embedded in polyvinyl alcohol mounting media with DABCO (PVA-DABCO, Sigma/Fluka).

LacZ staining. E15.5 brains were dissected and fixed with 2\% PFA in PBS overnight at $4^{\circ} \mathrm{C}$. After washing with PBS, brains were stained by X-gal staining buffer $\left(35 \mathrm{~mm} \mathrm{~K}_{4} \mathrm{Fe}(\mathrm{CN})_{6}, 35 \mathrm{~mm} \mathrm{~K}{ }_{3} \mathrm{Fe}(\mathrm{CN})_{6}, 2 \mathrm{~mm}\right.$ $\mathrm{MgCl}_{2}, 0.02 \% \mathrm{NP}-40,0.01 \% \mathrm{Na}$ deoxycholate, and $1 \mathrm{mg} / \mathrm{ml} \mathrm{X}$-gal in PBS) for $3 \mathrm{~h}$ at $37^{\circ} \mathrm{C}$, followed by washing with PBS. Stained brains were cut into $15 \mu \mathrm{m}$ sections by cryostat, and sections were embedded in PVA-DABCO.

BrdU birthdating analysis. Pregnant dams from the mating between $\mathrm{Ywhae}^{+/ \text {flox }}$ Y Ywhaz ${ }^{+/ K O} ;$ h GFAP-Cre ${ }^{+}$heterozygotes were injected intraperitoneally with $\mathrm{BrdU}$ (Sigma; $100 \mu \mathrm{g} / \mathrm{g}$ ) at E15.5, and then they were 


\begin{tabular}{|c|c|c|c|c|c|c|c|c|c|}
\hline$\varepsilon$ & $+/+$ & $+/ K 0$ & KO/KO & $+/+$ & $+/ K 0$ & KO/KO & $+/+$ & $+/ K 0$ & K0/K0 \\
\hline$\zeta$ & $+/+$ & $+/+$ & $+/+$ & $+/ K 0$ & $+/ K 0$ & $+/ K 0$ & KO/KO & KO/KO & KO/KO \\
\hline Observed & 14 & 33 & 0 & 29 & 64 & 0 & 12 & 0 & 0 \\
\hline Expected & 1 & 2 & 1 & 2 & 4 & 2 & 1 & 2 & 1 \\
\hline
\end{tabular}

injected with lethal dose of pentobarbital (Nembutal, $100 \mathrm{mg} / \mathrm{kg}$, intraperitoneally) at E18.5 to collect brains from embryos (Miller and Nowakowski, 1988; Soriano and Del Rio, 1991). The neurons born at each time point were visualized by staining with monoclonal anti-BrdU antibody. After taking photos of each genotype, the cortex was separated into 10 bins, and the percentage of BrdU-positive cells was calculated in each bin (Toyo-oka et al., 2003).

In vivo BrdU proliferation assay and cell cycle analysis. BrdU was injected into dams at E15.5, and embryos were collected after $30 \mathrm{~min}$ for the proliferation assay or at E16.5 for the cell cycle analysis. Then, the brain sections were stained using anti-BrdU and anti-Ki67 antibodies. The $\mathrm{BrdU}^{+}$cells and the $\mathrm{BrdU}{ }^{+} / \mathrm{Ki}^{-}{ }^{-}$cells were counted, and the percentage of $\mathrm{BrdU}^{+} / \mathrm{Ki}^{-}{ }^{-}$cells were calculated versus total $\mathrm{BrdU}^{+}$cells.

Cell staining. After washing cells by PBS, cells were fixed in 4\% PFA/ PBS at room temperature for $10 \mathrm{~min}$. After washing cells by TBS twice, the fixed cells were treated by $0.2 \%$ Triton X-100/TBS at room temperature for $10 \mathrm{~min}$, followed by incubation in blocking buffer (5\% BSA/ $0.1 \%$ Tween 20 in TBS) supplemented by $3 \%$ host serum of the second antibody for $30 \mathrm{~min}$. The cells were incubated with primary antibody overnight at $4^{\circ} \mathrm{C}$. After washing cells with TBS-T (TBS supplemented with $0.1 \%$ Tween 20 ) four times, the cells were incubated with the secondary antibody-conjugated different fluorophores for $30 \mathrm{~min}$ at room temperature. Then, the cells were washed by TBS-T and stained by DAPI $(300 \mathrm{~nm})$ for $10 \mathrm{~min}$ at room temperature. Finally, the stained cells were embedded in PVA-DABCO.

Microscopy and data analysis. Images of cells were acquired with a laser-scanning confocal microscopes (C1si; Nikon and SP2; Leica) equipped with Plan Apo $(20 \times 0.75 \mathrm{NA}, 40 \times 1.30 \mathrm{NA}$, or $60 \times 1.40 \mathrm{NA}$; Nikon $)$ or HCX PL APO $(5 \times 0.15 \mathrm{NA}, 20 \times 0.70 \mathrm{NA}, 40 \times 1.25 \mathrm{NA}$, or $63 \times 1.40 \mathrm{NA}$; Leica) objectives. Using the confocal microscopes, images were recorded using confocal software, EZ-C1 (Nikon) and LCS (Leica) and were saved as TIFF. Pixel positions, distances, and areas were measured on the digital images using the analysis function of the ImageJ (Rasband, 1997-2014). Image processing was performed by using Photoshop and Illustrator (Adobe).

In vitro neuronal migration assay. In vitro neuronal migration assays were performed as previously described (Tanaka et al., 2004). For rescue experiments, the granule cells were transfected by Lipofectamine 2000 while aggregates were being produced.

Pull-down analysis. Transfected-cells were lysed by NP-40 lysis buffer (50 mu Tris, pH 7.4, 150 mm NaCl, 1 mm EDTA, and 1\% NP-40). Protein lysates were precleared by incubating Protein-G Plus-Agarose (Santa Cruz Biotechnology) and normal mouse IgG (Jackson ImmunoResearch Laboratories) for $30 \mathrm{~min}$ at $4^{\circ} \mathrm{C}$. Supernatant was immunoprecipitated by anti-HA antibody conjugated Agarose (HA-Probe F-7, Santa Cruz Biotechnology) or anti-His antibodies plus Protein-G Plus-Agarose. Immunoprecipitates were washed by NP-40 washing buffer ( $50 \mathrm{~mm}$ Tris, $\mathrm{pH}$ 7.4, $300 \mathrm{~mm} \mathrm{NaCl}, 1 \mathrm{~mm}$ EDTA, and 0.5\% NP-40) four times, and immunoprecipitated proteins were separated by SDS-PAGE.

Lentivirus production. pLV-CAG, pMDLg/p RRE, pRSV.Rev, and pVSVG plasmids were kindly provided by Dr. Ikawa in Osaka University, Japan. EGFP-tagged $\delta$-catenin, EGFP-tagged $\beta$-catenin, EGFP-tagged $\alpha \mathrm{N}$-catenin, EGFP-Ndel1 (3A), and EGFP-Ndell (3E) were cloned into pLV-CAG vector, and piLenti-GFP-Scramble siRNA and piLenti-GFP$\delta$-catenin siRNA vectors were produced by the abm. Lentiviruses were produced by UCSF lentivirus core facility. Virus titers used in this manuscript were $0.5-2.5 \times 10^{7}$.

Spindle orientation. The measurement of spindle orientation was performed as described previously (Fish et al., 2006; Yingling et al., 2008).

Pair-cell analysis. A previously described protocol was used for analyzing the neural progenitor cell division (Sanada and Tsai, 2005).
Measurement of the activity of the Rho family of GTPases. The measurement of the activity of the Rho family of GTPases was performed as previously described (Nakagawa et al., 2001). Briefly, neuronal progenitor cells were lysed in lysis buffer (50 mm Tris, pH 7.2, 1\% Triton X-100, $0.5 \%$ sodium deoxycholate, $0.1 \%$ SDS, $500 \mathrm{~mm} \mathrm{NaCl}, 10 \mathrm{~mm} \mathrm{MgCl}_{2}, 10$ $\mu \mathrm{g} / \mathrm{ml}$ each of leupeptin and aprotinin, and $1 \mathrm{~mm}$ PMSF). Then, cell lysates were centrifuged at $13,000 \times g$ at $4^{\circ} \mathrm{C}$ for $10 \mathrm{~min}$, and equal volumes of lysates were incubated with GST-Rhotekin-RBD $(20 \mu \mathrm{g})$ or GST-PAK-CRIB $(20 \mu \mathrm{g})$ bound to glutathione beads at $4^{\circ} \mathrm{C}$ for $45 \mathrm{~min}$. The beads were washed four times with washing buffer (Tris buffer containing $1 \%$ Triton X-100, $150 \mathrm{~mm} \mathrm{NaCl}, 10 \mathrm{mM} \mathrm{MgCl}_{2}, 10 \mu \mathrm{g} / \mathrm{ml}$ each of leupeptin and aprotinin, and $0.1 \mathrm{~mm}$ PMSF). Bound active Rho, Rac1, and cdc42 proteins were separated by SDS-PAGE and detected by a monoclonal antibody against RhoA, Rac1 or cdc42.

EEG monitoring. EEG recordings were obtained using a time-locked video EEG monitoring system (Pinnacle Technologies) as previously described (Greenwood et al., 2009). Mice were surgically implanted in the left and right frontoparietal cortex with electrodes. Each mouse was anesthetized with ketamine and xylazine $(10 \mathrm{mg} / \mathrm{kg}$ and $1 \mathrm{mg} / \mathrm{kg}$ i.p., respectively) so that there was no limb-withdrawal response to a noxious foot pinch. Sterile, stainless-steel bone screw recording electrodes were placed epidurally through burr holes in the skull (one electrode on either side of the sagittal suture, approximately halfway between bregman and lambdoid sutures and $\approx 1 \mathrm{~mm}$ from the midline) using surface head-mount EEG hardware (Pinnacle Technologies). Electrodes were cemented in place with a fast-acting adhesive and dental acrylic. Two wires were laid on the shoulder muscles for EMG recording. Animals were allowed to recover for $3 \mathrm{~d}$ before experiments were initiated. Electrographic seizures were defined as high-frequency, high-voltage synchronized polyspike or paroxysmal sharp waves with amplitude $>2$-fold background that lasted $\geq 15$ s. Electrographic EEG seizures were analyzed by using SireniaScore software (Pinnacle Technologies) and confirmed by offline review. Experimental animals were monitored for $7-19 \mathrm{~d}(24 \mathrm{~h} / \mathrm{d})$. A total of 63,228 $\min (43 \mathrm{~d})$ of recording were analyzed for control mice $(n=5)$ and $89,212 \min (61 \mathrm{~d})$ for dKO mice $(n=5)$.

Statistical analysis. Quantitative data were subjected to statistical analysis by using several statistical and biological software packages including KyPlot (KyensLab) and Prism (GraphPad Software). The data were analyzed by the single-factor ANOVA with Dunnett's post-test unless otherwise stated. Results were deemed statistically significant if the $p$ value is $<0.05$. Data are shown as the mean \pm SEM unless otherwise stated. For Western blot analysis and the measurement of the activity of Rho GTPases, semiquantitative analysis was performed by using ImageJ (Rasband, 1997-2014).

\section{Results}

\section{Production of double Ywhae and Ywhaz conventional and} conditional knock-out mice

To analyze the functions of the 14-3-3 proteins in neurogenesis, we produced Ywhae/Ywhaz $\mathrm{dKO}$ mice using conventional null alleles for Ywhae (Toyo-oka et al., 2003) and Ywhaz (Cheah et al., 2011). Ywhae $e^{+/ K O} ; Y_{w h a z}{ }^{+/ K O}$ mice were able to live until adulthood and were smaller than the wild-type mice, whereas $Y w h a e^{+/ K O}$; $Y w h a z^{K O / K O}$ or Ywhae $e^{K O / K O}$; Ywhaz ${ }^{K O / K O} \mathrm{KO}$ mice die in the early stages of embryogenesis (Table 1), perhaps a result of the role of 14-3-3e in cardiac compaction (Kosaka et al., 2012). Therefore, we produced conditional Ywhae KO mice (Ywhae $e^{\text {flox/flox }}$ ) to avoid this early lethality (Fig. $1 A, B$ ). The neomycin-resistant gene cassette flanked by FRT sequences was targeted into the intron 4 of the Ywhae gene, and the neomycin resistant gene cassette was removed by mating with Flpe transgenic mice (Fig. $1 A, B)$. To confirm that the targeting strategy works in vivo, the $Y$ whae $e^{\text {flox/flox }}$ mice were mated with $h$ GFAP-Cre transgenic mice to express Cre recombinase in the radial glial cells and their progeny, including neurons (Zhuo et al., 2001; Yingling et al., 2008), and the tails and cerebral cortices were collected at P15. Genomic DNA prepared from tails and cortices were analyzed by PCR (Fig. 
1C). KO allele was detected in cortical DNA, but not tail DNA. However, the flox allele was detected in both cortex and tail, indicating that the recombination efficiency by Cre recombinases was not complete in the cortex of the Ywhae flox/flox; hGFAP-Cre ${ }^{+}$ mice. To determine the efficiency of the recombination, $h G F A P$ Cre mice were mated with the ROSA26 mice, and LacZ staining was performed on the ROSA26 ${ }^{+}$; $h \mathrm{GFAP}-\mathrm{Cr} e^{+}$mice at E15.5 (Fig. 1D). As expected, almost all of the cells in the cortex were lacZ positive, but in some cells lacZ staining was negative or very weak. To confirm that the expression of the 14-3-3 $\varepsilon$ proteins was significantly decreased in the Ywhae $e^{\text {flox/flox }}$; $h$ GFAP-Cre $e^{+}$mice, we performed Western blot analysis (Fig. 1E) and immunohistochemistry (Fig. $1 F$ ). Western blot analysis revealed that the expression of the $14-3-3 \varepsilon$ proteins in the cortex of the Ywhae flox/flox; $h G F A P$ $\mathrm{Cre}^{+}$mice was faint (Fig. 1E), consistent with the results obtained from PCR and LacZ staining (Fig. 1C,D). In addition, immunohistochemical analysis indicated that the expression of the 143-3 $\varepsilon$ proteins was almost completely abolished in the E15.5 cortex of the Ywhae flox/flox; hGFAP-Cre ${ }^{+}$mice (Fig. 1F). These data indicate that the Ywhae gene was effectively inactivated in the Ywhae flox/flox; $h$ GFAP-Cre $e^{+}$mice.

We mated the Ywhae flox/flox mice with the Ywhaz KO mice to produce conditional Ywhae/Ywhaz dKO mice and used hGFAPCre transgenic mice to inactivate Ywhae in the developing cortex. Almost all Ywhae flox/flox; Ywhaz ${ }^{K O / K O} ;$ hGFAP-Cre ${ }^{+}$mice (complete $\mathrm{dKO}$ ) died before E15.5, whereas all other genotypes were born and survived until adulthood (Table 2). Therefore, we primarily analyzed $Y w h a e^{+/ f l o x} ; Y_{w h a z}{ }^{K O / K O} ; h G F A P-C r e^{+}$mice and $Y$ whae $e^{\text {flox/flox }} ; Y w h a z^{+/ K O} ; h G F A P-C r e^{+}$mice (dKO), using wildtype $\left(Y_{w h a e^{+/+}} ; \mathrm{Ywhaz}^{+/+} ;\right.$hGFAP-Cre $\left.{ }^{+}\right)$or single mutants for either Ywhaz (Ywhae ${ }^{+/ f l o x} ; Y_{w h a z}{ }^{K O / K O} ;$ hGFAP-Cre $\left.{ }^{-}\right)$or Ywhae $\left(Y_{w h a e^{\text {flox/flox }} ; \mathrm{Ywhaz}^{+/+} ; \text {hGFAP-Cre }}{ }^{+}\right)$. Nissl staining revealed that the boundary between intermediate zone (IZ) and cortical plate $(\mathrm{CP})$ was obscure in the $\mathrm{dKO}$ mice, and the cell density was lower in the $\mathrm{dKO}$ mice compared with wild-type control mice. Single mutants displayed intermediate phenotypes (Fig. $1 G$ ).

Many dKO mice survived into adulthood, although some occasionally died after 2 months (Fig. $1 H$; Kaplan-Meier survival test, $p=0.043)$. dKO mice often displayed handling-induced seizures when they were placed into a new cage, which may be a cause of their lethality. These seizures lasted $\sim 15 \mathrm{~s}$, the head turned upward, and the body swayed back and forth, similar to Racine Class II seizure behaviors described previously (Racine et al., 1979). To examine whether $\mathrm{dKO}$ mice also displayed spontaneous electrographic seizures, we performed continuous EEG monitoring (7-19 d) from freely behaving animals at 2-3 months of age (Fig. 1I). In two of five dKO mice, we observed spontaneous seizures consisting of high-frequency, high-voltage, rhythmic activity with clear onset and termination of ictal events (frequency: 0.69 and 1.74 seizures per day, duration $59.0 \pm 6.4$ and $45.1 \pm 3.4 \mathrm{~s}$ ). Electrographic seizures or high-voltage spiking were never observed in control animals $(n=5)$.

\section{Deficiency of Ywhae and Ywhaz in radial glial cells resulted in abnormal proliferation and differentiation of neural progenitor cells}

To determine whether these mice display proliferation defects during neurogenesis, we injected pregnant dams with BrdU at E15.5 and, after 30 min, collected embryos for BrdU immunostaining. In control mice (wild-type), $\mathrm{BrdU}^{+}$cells were predominantly localized in the VZ and SVZ (Fig. $1 \mathrm{~J}, K$ ). Single mutants for either Ywhae or Ywhaz displayed a nonsignificant tendency toward increased $\mathrm{BrdU}^{+}$cells in the $\mathrm{VZ}, \mathrm{SVZ}$, and IZ. In the $\mathrm{dKO}$ mice, the number of BrdU ${ }^{+}$cells was increased in the VZ, SVZ, and IZ (Fig. $1 \mathrm{~J}, K$ ). Next, because we found the increased number of proliferating progenitor cells in the $\mathrm{dKO}$ mice, especially in the SVZ where IPCs are localized (Fig. $1 K$ ), we analyzed the number of Tbr $2^{+}$IPCs. There was an increased number of Tbr $2^{+}$IPCs in the single mutant mice as well as the $\mathrm{dKO}$ mice (Fig. $1 L, M$ ) that were more broadly distributed throughout the cortex of $\mathrm{dKO}$ mice than control wild-type, where IPCs were predominantly localized in the SVZ (Fig. 1N). These data indicate that the 14$3-3 \varepsilon$ and $14-3-3 \zeta$ proteins together are essential for the production and maintenance of the proper number and position of IPCs.

\section{4-3-3 deficiency resulted in increased differentiation of neural progenitor cells into neurons}

If the increased number of IPCs found in the 14-3-3 dKO mice predominantly differentiate into neurons, it is expected that they will primarily exit rather than reenter the cell cycle. BrdU was injected into pregnant dams at E15.5, and embryos were collected at E16.5. Brain sections were immunostained with anti-BrdU and anti-Ki67 antibodies. Single-mutant mice did not demonstrate statistically significant increases of the number of $\mathrm{BrdU}^{+} / \mathrm{Ki}^{-}$ cells. In contrast, the number of $\mathrm{BrdU}^{+} / \mathrm{Ki}^{-} 7^{-}$cells exiting the cell cycle was increased in the VZ and SVZ of dKO compared with the control wild-type mice (Fig. 2A,B). These data indicate that the combined loss of Ywhae and Ywhaz results in cell cycle exit of the progenitor cells, and this might result in more neurons (and/or IPCs) in the cortex.

When RG cells divide asymmetrically, one progenitor cell and one neuron are produced. Therefore, it is possible that the 14-3-3 deficiency results in more frequent asymmetric cell division in the RG cells. One potential measure of asymmetric versus symmetric division is the division angle or spindle orientation of RG cells. In the wild-type control mice at E15.5, most of the cells divided symmetrically, with a spindle orientation of $70^{\circ}-80^{\circ}$ (Fig. $2 C, D)$. In contrast, there were more asymmetrically dividing cells in the $\mathrm{dKO}$ mice, with average spindle orientations of $<70^{\circ}$ (Fig. $2 C, D)$. Single mutants demonstrated intermediate, nonsignificant phenotypes. There were no genotype differences in spindle orientation at E18.5 (data not shown), suggesting that the combined effect of $14-3-3 \varepsilon$ and $14-3-3 \zeta$ contributes to proper spindle orientation during neurogenesis. As a more direct test of this hypothesis, we used the pair-cell analysis combined with the staining of neuronal progenitor cell markers, Sox2 and Tbr2. There are four different possible paired cell phenotypes that represent cell divisions (Fig. 2E): neuron-neuron, with both cells positive for $\mathrm{TuJ} 1$; neuron-progenitor, with one cell positive for TuJ1 and the other positive for Sox 2; progenitor-progenitor division, with both cells negative for TuJ1 but positive for Sox 2 ; and progenitor-progenitor division, with both cells negative for TuJ1 but positive for Tbr2. Neuron-progenitor divisions in which one cell was positive for Tuj 1 and the other positive for Tbr2 were not observed. Consistent with an increase in neurogenesis, 14-3-3 $\mathrm{dKO}$ progenitor cells displayed neuron-neuron and neuronprogenitor paired cell divisions more frequently than the control cells (Fig. 2F).

Finally, we cultured neural progenitor cells in vitro by producing neurospheres and tested whether neurosphere differentiation was affected in 14-3-3 dKO progenitors (Fig. 2G-I). Before differentiating into neurons, there was no difference in the ratio of the Sox ${ }^{+}$and $\mathrm{Tbr} 2{ }^{+}$progenitor cells between wild-type control mice and the dKO mice (Fig. $2 G$ ). However, when the neuro- 
Table 2. Genotype ratio from mating the Ywhae ${ }^{+/ f l o x} ; Y_{w h a z}+/ K o ; h G F A P-C r e^{+}$mice

\begin{tabular}{|c|c|c|c|c|c|c|c|c|c|c|c|c|c|c|c|c|c|c|}
\hline$\varepsilon$ & $+1+$ & $+1+$ & $+1+$ & $+/ f$ & $+/ f$ & $+/ f$ & $f / f$ & $f / f$ & $f / f$ & $+1+$ & $+1+$ & $+1+$ & $+/ f$ & $+/ f$ & $+/ f$ & $f / f$ & $f / f$ & $f / f$ \\
\hline$\zeta$ & $+1+$ & $+1-$ & $-1-$ & $+1+$ & $+1-$ & $-1-$ & $+1+$ & $+1-$ & $-1-$ & $+1+$ & $+1-$ & $-1-$ & $+1+$ & $+1-$ & $-1-$ & $+1+$ & $+1-$ & $-1-$ \\
\hline Cre & - & - & - & - & - & - & - & - & - & + & + & + & + & + & + & + & + & + \\
\hline Observed & 3 & 4 & 3 & 5 & 12 & 4 & 2 & 4 & 3 & 2 & 7 & 2 & 5 & 10 & 4 & 4 & 9 & 0 \\
\hline Expected & 1 & 2 & 1 & 2 & 4 & 2 & 1 & 2 & 1 & 1 & 2 & 1 & 2 & 4 & 2 & 1 & 2 & 1 \\
\hline
\end{tabular}

A
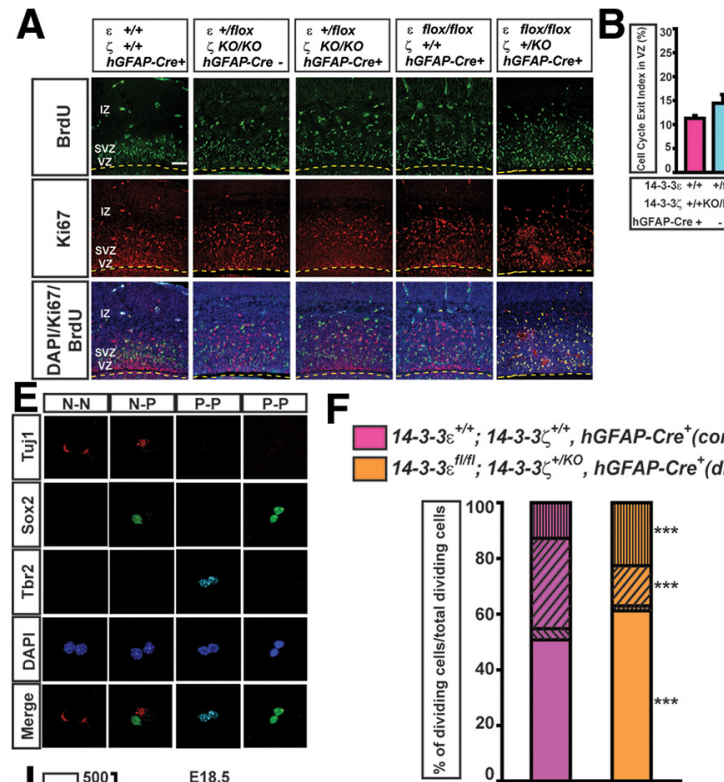

$\mathbf{F}$

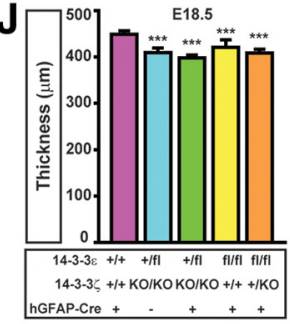

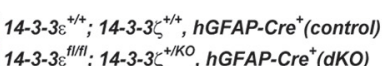
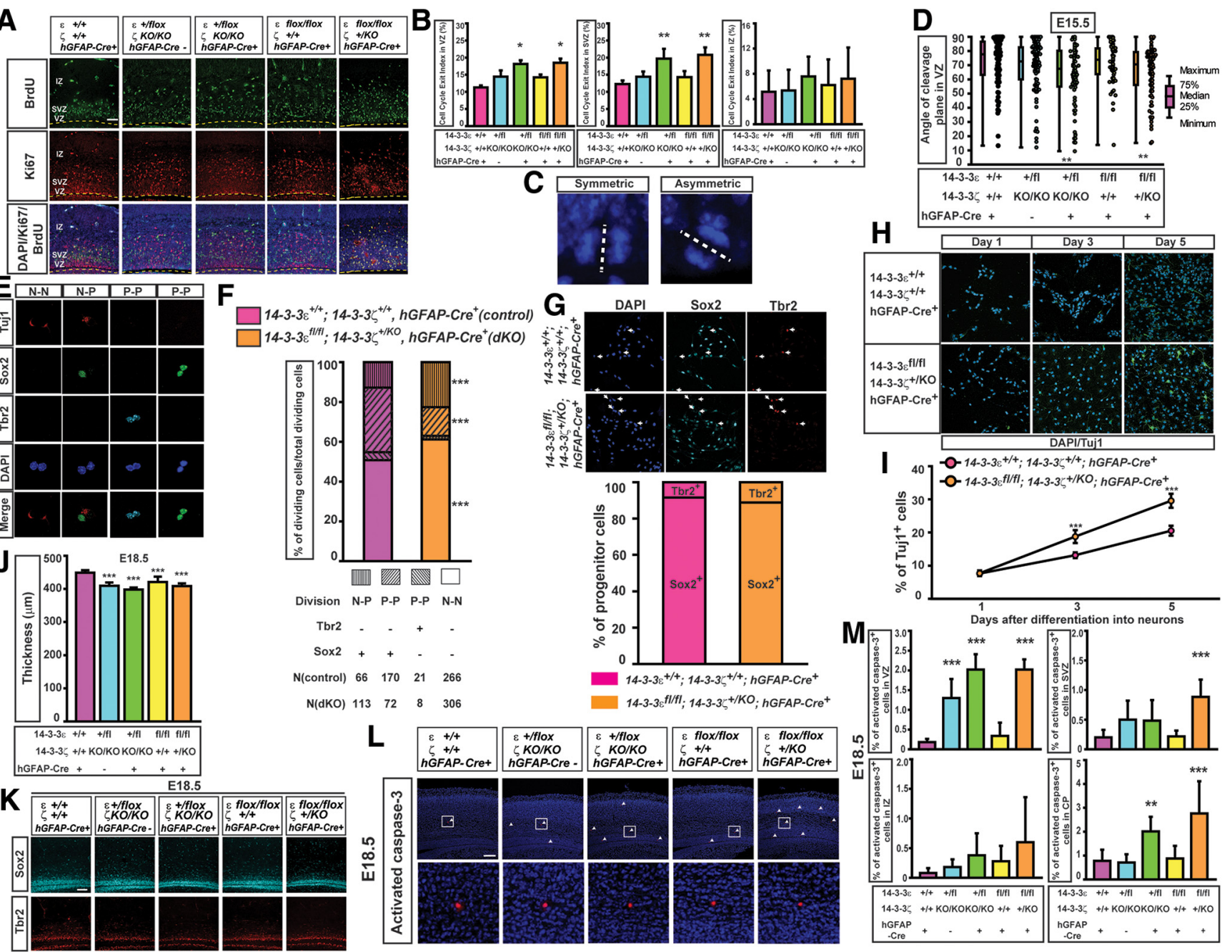

Figure 2. 14-3-3 regulates cell cycle exit, differentiation, and apoptosis of neurons. A, Immunohistochemistry with anti-BrdU and anti-Ki67 antibodies on the dK0 mice at E16.5. Scale bar, $50 \mu \mathrm{m}$. $B$, Cell cycle exit index (\% of BrdU ${ }^{+} / K_{i 67}{ }^{-}$cells/total BrdU ${ }^{+}$cells) in the VZ, SVZ, and IZ. ${ }^{*} p<0.05 .{ }^{* *} p<0.01 . n=5$ or 6 areas from three animals per genotype. $C$, Two examples of the symmetrically or asymmetrically dividing RGCs in the VZ. Dotted lines indicate the angle of cell division as a measure of spindle orientation. D, Quantification of the spindle orientation in the RGCS. Data are shown as the median $\pm 25 \%-75 \%$ distribution. Error bars indicate maximum and minimum values for each genotype. ${ }^{* *} p<0.01 . n=61-106$ cells for E15.5 from three animals per genotype. $E$, Examples of four types of cell pairs: two neurons (N-N, Tuj1 double-positive, left panels); a progenitor cell and a neuron (N-P, one cell positive for TuJ1 and the other positive for Sox2, second panels from left); two progenitor cells (P-P, Tuj1 double-negative, but Sox2 double-positive, second panels from right); and two progenitor cells (P-P, Tuj1 double-negative, but Tbr2 double-positive, right panels). $\boldsymbol{F}$, Quantification of the in vitro pair cell analysis. ${ }^{* * *} p<0.001$ (two-way ANOVA followed by the Bonferroni test). $n=5$ areas from three animals per genotype. $\boldsymbol{G}$, Immunofluorescence of neurosphere cells before the induction of neuronal differentiation. Top, Ywhae ${ }^{+/+} ; Y_{w h a z}{ }^{+/+} ;$hGFAP-Cre $e^{+}$. Bottom, $Y_{w h a e^{f l / f l} ; Y_{w h a z}}^{+/ K 0} ;$ hGFAP-Cre ${ }^{+}$. Right, Quantification of the ratio of the two different types of neural progenitor cells: radial glial cells, Sox2 ${ }^{+}$, and intermediate progenitor cells, $\mathrm{Tbr2}^{+}$. $\boldsymbol{H}$, Neuronal differentiation assay. Immunohistochemistry with anti-Tuj 1 antibody on the dKO mice at day 1 , day 3 , and day $5 . I$, Quantification of the Tuj ${ }^{+}$cells in the neuronal differentiation assay. $n=6-10$ areas from three animals per genotype. ${ }^{* * *} p<0.001$ (two-way repeated-measures ANOVA followed by the Bonferroni test).J, Quantification of the cortical thickness at E18.5. $n=4-8$ animals per genotype. Data are shown as the mean \pm SD. ${ }^{* * *} p<0.001 . K$, Immunohistochemistry of Sox2 (VZ) and Tbr2 (SVZ) atE18.5. Scale bar, $50 \mu \mathrm{m}$. L, Immunohistochemistry of activated caspase- $3^{+}$apoptotic cells atE18.5 (top). Bottom, High-magnification views of the square region in the top panels. Scale bar, $100 \mu \mathrm{m}$. Arrowheads indicate the activated caspase- $3^{+}$apoptotic cells. $\boldsymbol{M}$, Quantification of apoptotic cells at the VZ (top left), SVZ (top right), IZ (bottom left), and CP (bottom right). ${ }^{* *} p<0.01 .{ }^{* *} p<0.001 . n=5-8$ areas from three animals per genotype.

spheres were differentiated into neurons, the neurospheres from dKO mice differentiated more frequently into neurons than neurospheres from wild-type control cells (Fig. $2 \mathrm{H}, \mathrm{I}$ ).

These findings indicate that the combined effect of $14-3-3 \varepsilon$ and $14-3-3 \zeta$ proteins is important for the differentiation of neu- ral progenitor cells into neurons. Although the dKO mutants displayed an increased number of neural progenitor cells and neurons, the brain size of the single and dKO mice was smaller than that of the wild-type control mice only at E18.5, but not at E15.5 (Fig. 2J; and data not shown). Consistent with these obser- 


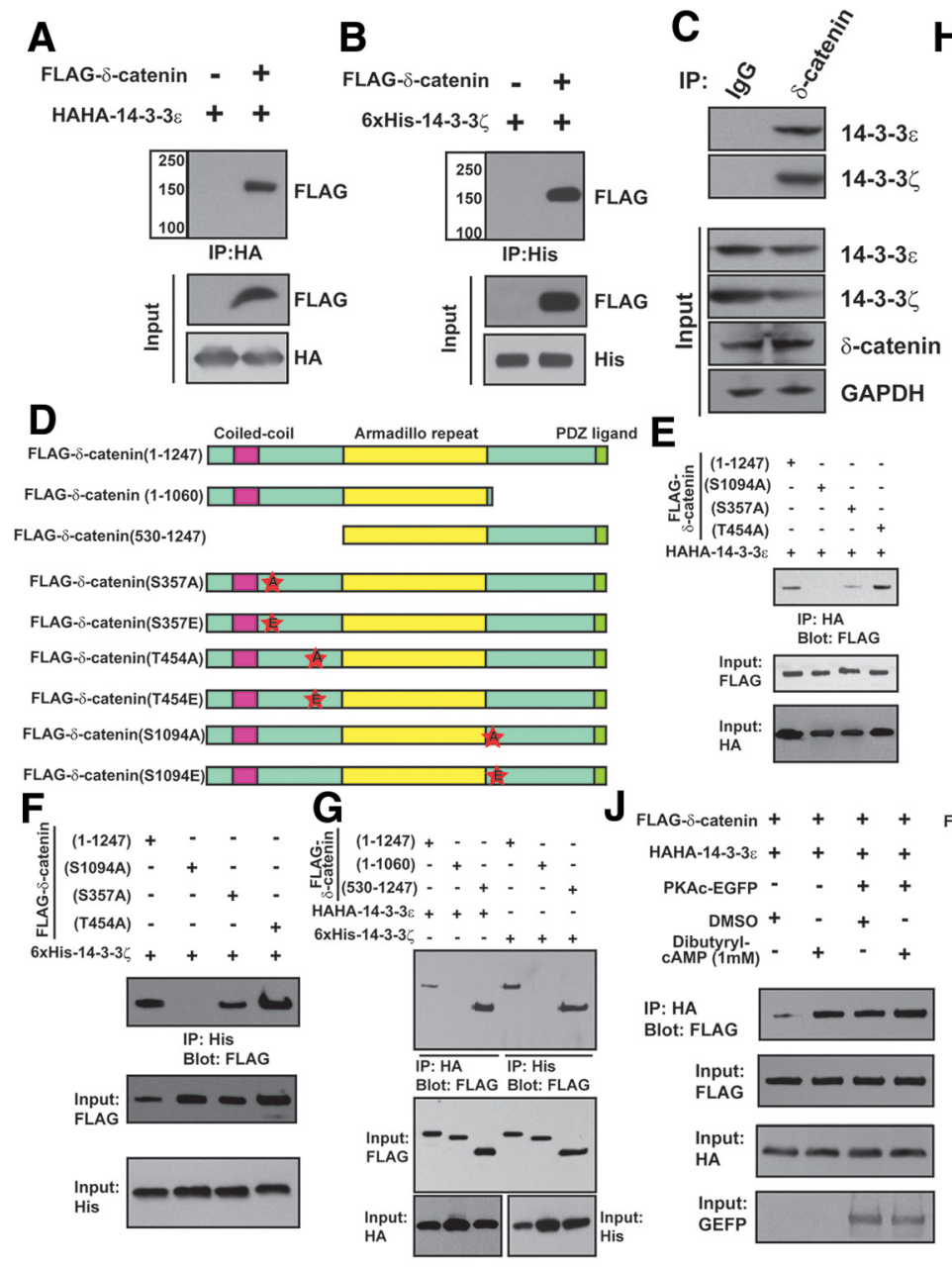

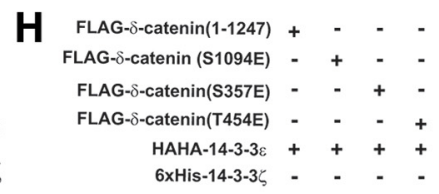
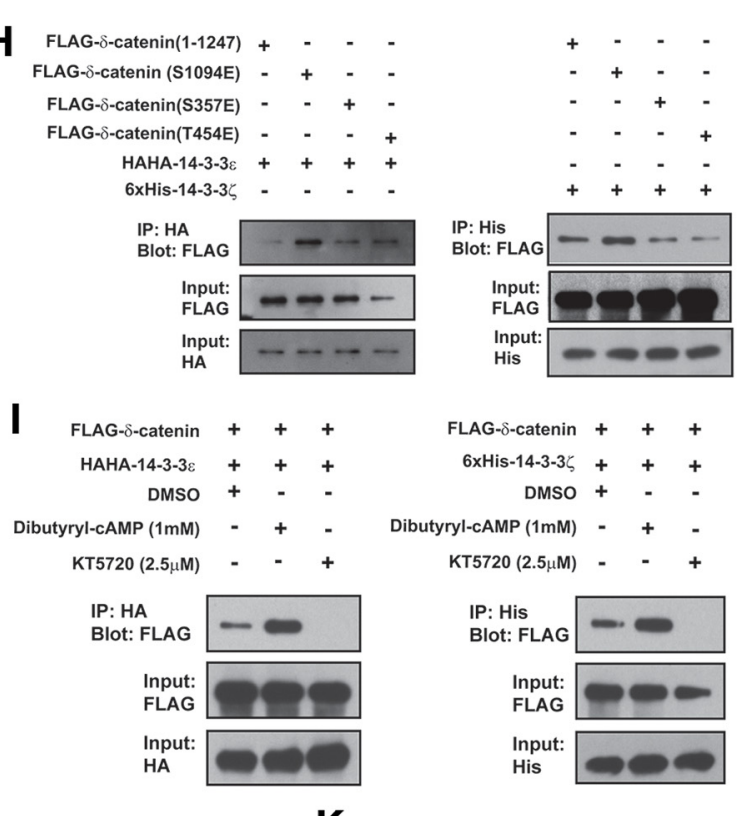
FLAG- $\delta$-catenin +++
6 xHis-14-3-3 $\zeta+++$
DMSO + - -
Dibutyryl-cAMP (1mM) - + -

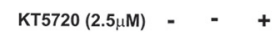

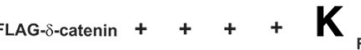
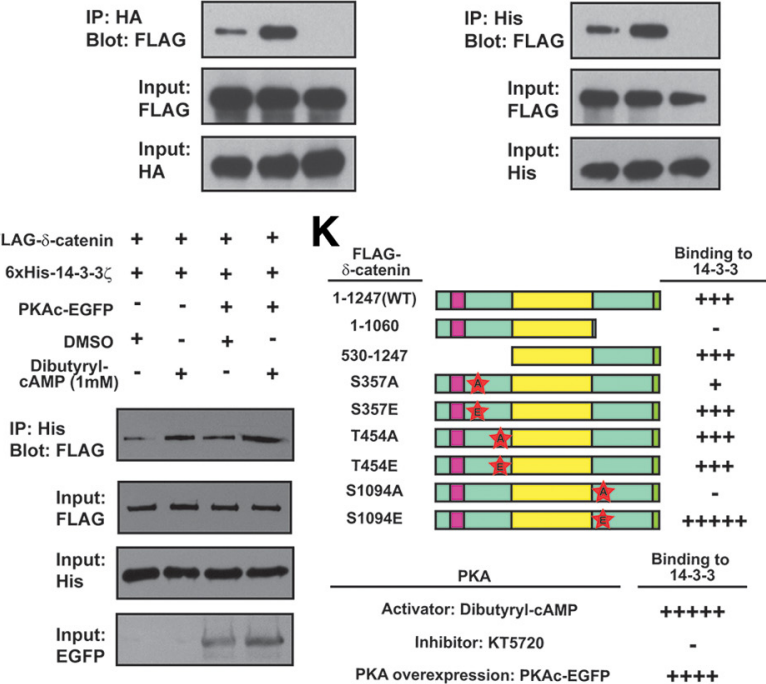

Figure 3. $14-3-3$ binds to $\delta$-catenin. $A$, Coimmunoprecipitation of FLAG- $\delta$-catenin by HAHA-14-3-3 $\varepsilon$. $B$, Coimmunoprecipitation of FLAG- $\delta$-catenin by 6 xHis-14-3-3 $\zeta$. $C$, Endogenous $\delta$-catenin interacts with endogenous 14-3-3 proteins. Brain lysates are immunoprecipitated by anti- $\delta$-catenin antibody followed by blotting by anti-14-3-3 $\varepsilon$ and anti-14-3-3 $\zeta$ antibodies. $D, S$ chematic illustration showing truncation mutants and point mutants of FLAG- $\delta$-catenin. $\boldsymbol{E}, \mathrm{S}$ 1094A mutation of $\delta$-catenin abolishes the interaction between $\delta$-catenin and 14-3-3 $\varepsilon$. $F$, S1094A mutation of $\delta$-catenin abolishes the interaction between $\delta$-catenin and $14-3-3 \zeta . \mathbf{G}, 14-3-3$ proteins preferentially bind to $C$ terminus of $\delta$-catenin. $\boldsymbol{H}, 14-3-3$ proteins preferentially bind to phosphomimetic $\delta$-catenin proteins. $I$, Ser1094 is phosphorylated by PKA. FLAG- $\delta$-catenin-transfected COS1 cells were treated with DMSO (left lane), PKA activator, dibutyryl-cAMP (middle lane), and PKA inhibitor, KT 5720 (right lane) in $24 \mathrm{~h}$ after transfection. $J$, The binding between $14-3-3$ and $\delta$-catenin is accelerated by the overexpression of PKA. FLAG- $\delta$-catenin-transfected $293 \mathrm{~T}$ cells were treated with DMSO (left lane) or dibutyryl-cAMP (second lane from left). Also, FLAG- $\delta$-catenin-transfected $293 \mathrm{~T}$ cells were subjected to overexpression of EGFP-tagged PKA catalytic subunit combined with DMSO (second lane from right) or dibutyryl-cAMP (right lane) treatment. $\boldsymbol{K}$, Summary of the interaction between the 14-3-3 and $\delta$-catenin proteins.

vations, Sox2 and Tbr2 immunostaining demonstrated that the $\mathrm{VZ}$ and SVZ in the dKO mice were thinner than control mice (Fig $2 \mathrm{~K})$. One possibility is that neurons die more frequently in the 14-3-3 mutant mice. To test this hypothesis, we determined whether the $\mathrm{dKO}$ mice displayed increased numbers of apoptotic cells in the cortex. We found the increased activated caspase-3 positive apoptotic neurons in the $\mathrm{dKO}$ mice at E18.5, but not at E15.5 (Fig. 2L, M; and data not shown) in the VZ, SVZ, and CP.

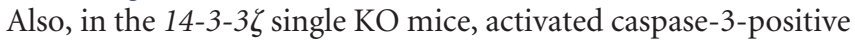
apoptotic neurons were significantly increased in the $\mathrm{VZ}$ and $\mathrm{CP}$, suggesting that the 14-3-3 $\zeta$ proteins are important for progenitor cell survival. Thus, the $14-3-3 \varepsilon$ and $14-3-3 \zeta$ proteins together regulate the differentiation of progenitor cells into neurons and neuronal survival during brain development.

\section{4-3-3 proteins bind to $\delta$-catenin and regulate its} ubiquitin-mediated degradation

We next performed proteomic analysis to find possible 14-3-3E and $14-3-3 \zeta$ binding partners involved in these phenotypes and found that these 14-3-3 proteins strongly bind to $\delta$-catenin (ct- $n n d 2)$ (data not shown). Previous studies indicate that $\delta$-catenin is important for neuronal morphology and synaptic functions (Israely et al., 2004; Arikkath et al., 2009). However, there are no studies that investigated the functions of $\delta$-catenin during neurogenesis.

To confirm that $14-3-3 \varepsilon$ and $14-3-3 \zeta$ proteins bind to $\delta$-catenin, we performed pull-down analysis. 14-3-3e (Fig. $3 A$ ) and $14-3-3 \zeta$ (Fig. $3 B$ ) both clearly bind to $\delta$-catenin in COS1 cells, and this was confirmed using antibodies to endogenous proteins in the brain (Fig. 3C). These data suggest that the 14-3-3 and $\delta$-catenin proteins bind in the developing brain.

Previous studies demonstrated that $14-3-3 \zeta$ binds to $\$ 1094$ of $\delta$-catenin (Mackie and Aitken, 2005). Other studies demonstrated that S357 and T454 are phosphorylated by Cdk5 and Akt1, respectively, and these phosphorylation sites are potential 14-3-3 protein binding sites (Kim et al., 2008; Poore et al., 2010). Therefore, we produced serine/threonine to alanine mutants for each of these three residues to eliminate phosphorylation (S357A, T454A, and S1094A; Fig. 3D). By using these mutants, we demonstrated that both $14-3-3 \varepsilon$ and $14-3-3 \zeta$ proteins bound to the 

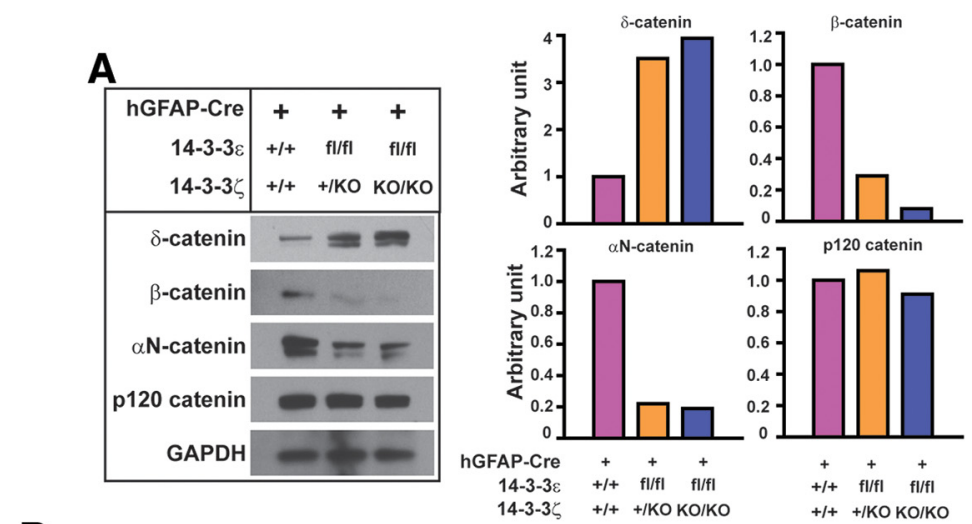

B
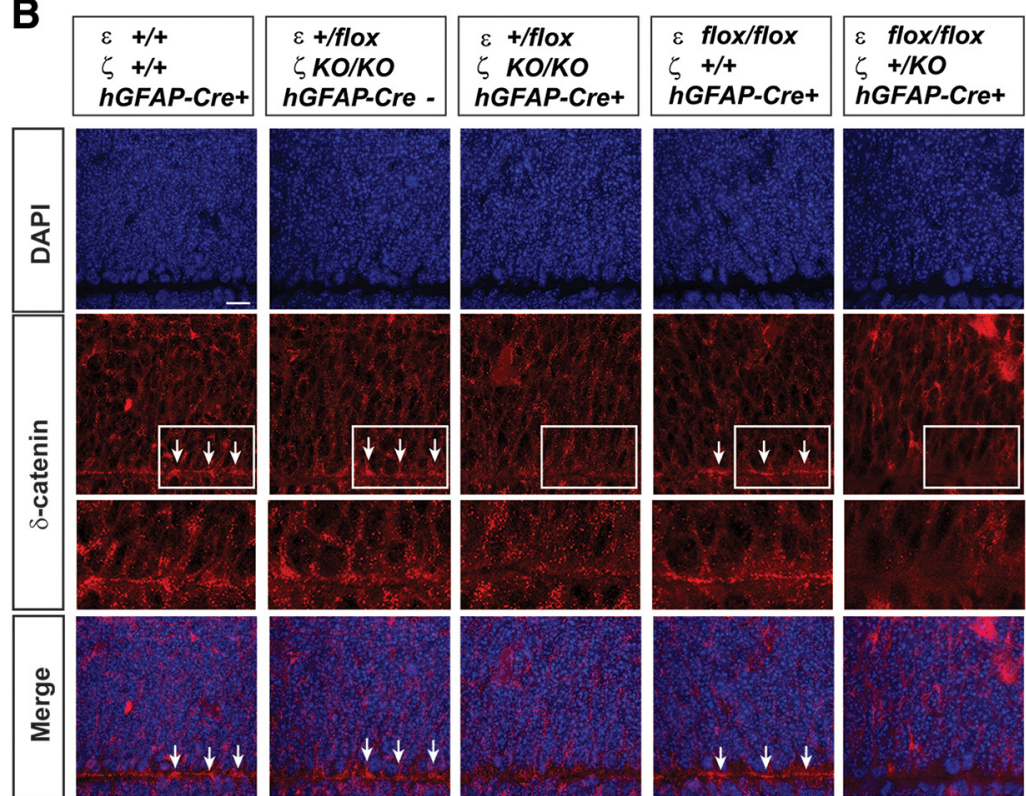

C
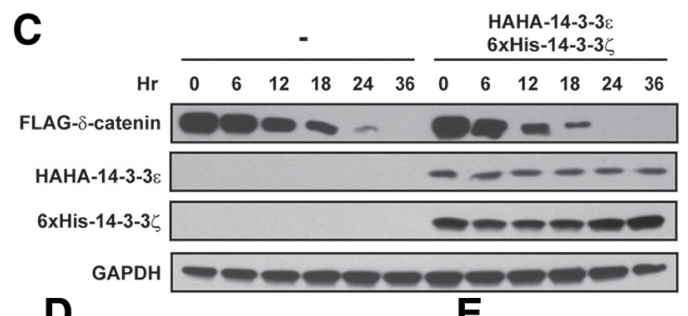

D
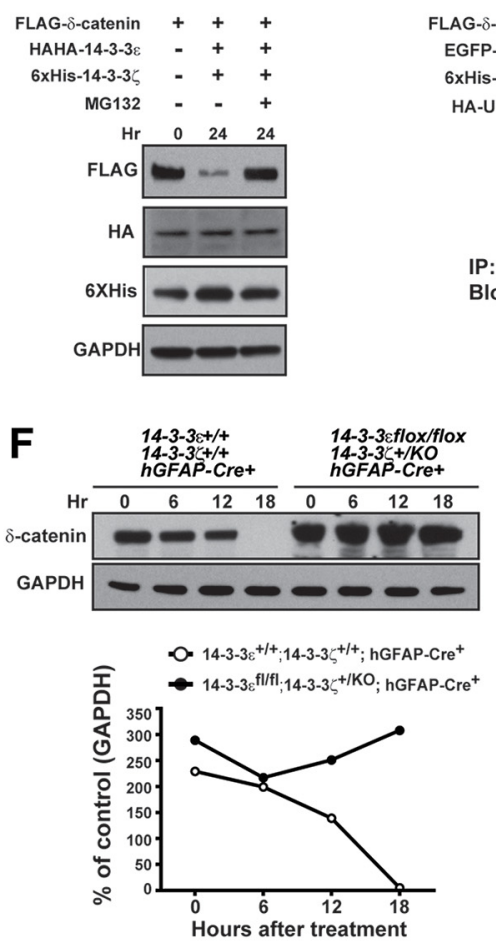

E

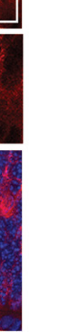

Figure 4. 14-3-3 controls the stabilization of $\delta$-catenin by the ubiquitin proteolysis system. $A$, Immunoblot analysis of catenin proteins in neuronal progenitor cells. Right, Quantification of the relative expression of the catenin proteins. $\boldsymbol{B}$, Immunohistochemistry with anti- $\delta$-catenin antibody on the dKO mice. Scale bar, $10 \mu \mathrm{m}$. Arrows indicate predominant localization of the $\delta$-catenin proteins at the apical surface of the VZ. Bottom panels in $\delta$-catenin staining are high-magnification views of the boxed regions of the top. $\boldsymbol{C}$, 0 verexpression of $14-3$-3 proteins accelerated the turnover of $\delta$-catenin proteins. $\boldsymbol{D}$, Accelerated turnover of $\delta$-catenin proteins by 14-3-3 overexpression was rescued by the ubiquitin inhibitor MG132. $\boldsymbol{E}$, 0verexpression of $14-3-3$ proteins accelerated the turnover of $\delta$-catenin proteins via ubiquitination. The 293T cells were cotransfected with FLAG- $\delta$-catenin and HA-ubiquitin (left lane) or FLAG- $\delta$-catenin, HA-ubiquitin, EGFP-143-3 $\varepsilon$, and 6 XHis-14-3-3 $\zeta$ (right lane). $F$, Stabilization of endogenous $\delta$-catenin proteins by the 14-3-3 deficiency in neuronal progenitor cells.

S357A or T454A mutants, but not the S1094A mutant, although the S357A mutation also significantly decreased binding between $14-3-3$ and $\delta$-catenin proteins (Fig. $3 E, F$ ), strongly suggesting that 14-3-3 proteins bind to serine 1094. Consistent with this, both $14-3-3 \varepsilon$ and $14-3-3 \zeta$ proteins bound to the C-terminal (1061-1247) region of the $\delta$-catenin because both proteins were able to bind to the $\mathrm{N}$ terminus deletion mutant (residues $530-$ 1247), but not $\mathrm{C}$ terminus deletion mutant (1-1060; Fig. 3G). Next, we tested whether binding was phosphorylation dependent. We produced mutants in which a serine/threonine is replaced with glutamic acid to mimic phosphorylation (S357E, T454E, and S1094E; Fig. 3D). The $\delta$-catenin S1094E mutant strongly interacted with both $14-3-3 \varepsilon$ and $14-3-3 \zeta$ proteins (Fig. $3 H$ ), whereas the S357E and T453E mutants bound similarly to wild-type (1-1247), supporting the importance of phosphorylation

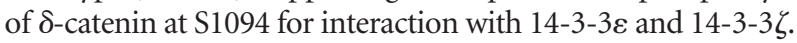

Finally, to investigate the kinase responsible for phosphorylation of $\delta$-catenin at $\mathrm{S} 1094$, we used the web-based prediction programs of kinase-specific phosphorylation sites, NetPhosK 1.0 (http://www.cbs.dtu.dk/services/NetPhosK/) and pkaPS (http:// mendel.imp.ac.at/sat/pkaPS/), and found that $\mathrm{S} 1094$ is a poten- tial phosphorylation site for protein kinase A (PKA). To test this hypothesis, we used the PKA specific activator, dibutyryl-cAMP and inhibitor, KT5720 (Fig. 3I). Treatment with the PKA activator, dibutyryl-cAMP increased the binding between 14-3-3 and $\delta$-catenin proteins, whereas treatment with the PKA inhibitor, KT5720, attenuated their binding. To further test the importance of PKA in the phosphorylation of $\delta$-catenin, we overexpressed the PKA catalytic subunit (PKAc) to analyze whether this overexpression accelerates the association between 14-3-3 and $\delta$-catenin proteins. As expected, overexpression of PKAc and the combination of dibutyryl-cAMP treatment and PKAc overexpression increased the association between 14-3-3 and $\delta$-catenin proteins (Fig. $3 J$ ). These data suggest that PKA is a potential kinase of the $\mathrm{S} 1094$ site of the $\delta$-catenin proteins.

\section{4-3-3 proteins regulate the ubiquitin-mediated degradation} of $\delta$-catenin

To analyze whether the deficiency of these 14-3-3 proteins affected the expression of $\delta$-catenin, we performed Western blot analysis by using neurospheres from wild-type control mice, $\mathrm{dKO}$ mice (Ywhae flox/flox; Ywhaz ${ }^{+/ K O} ;$ hGFAP-Cre ${ }^{+}$), and com- 


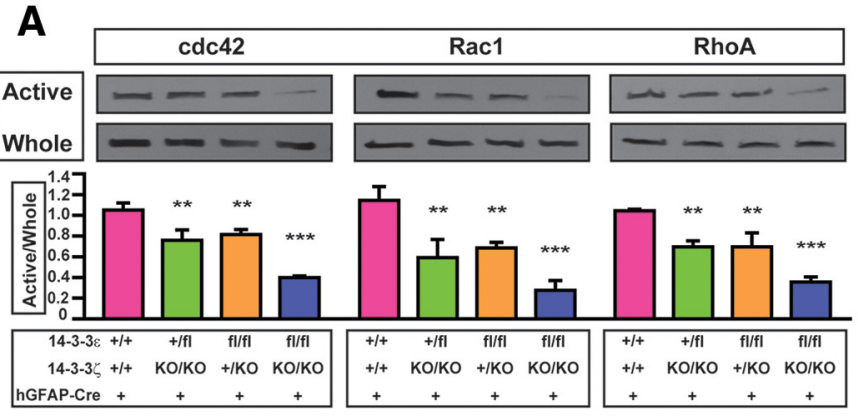

B
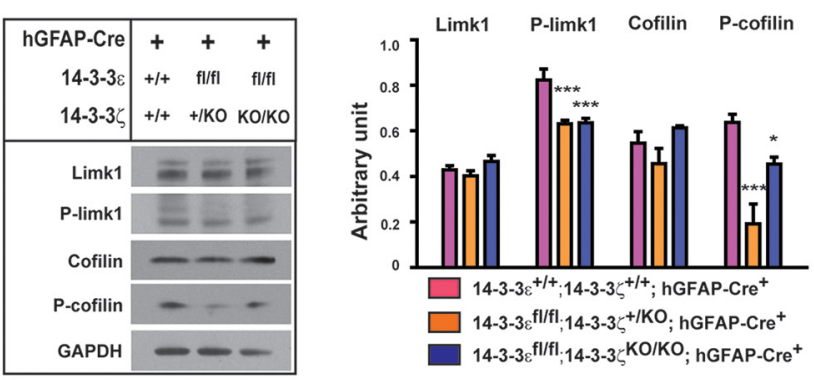

C

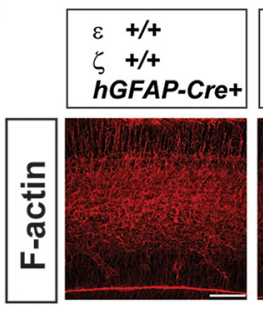

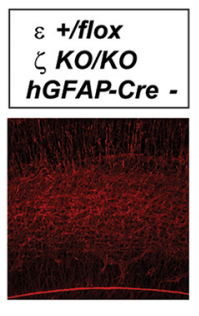
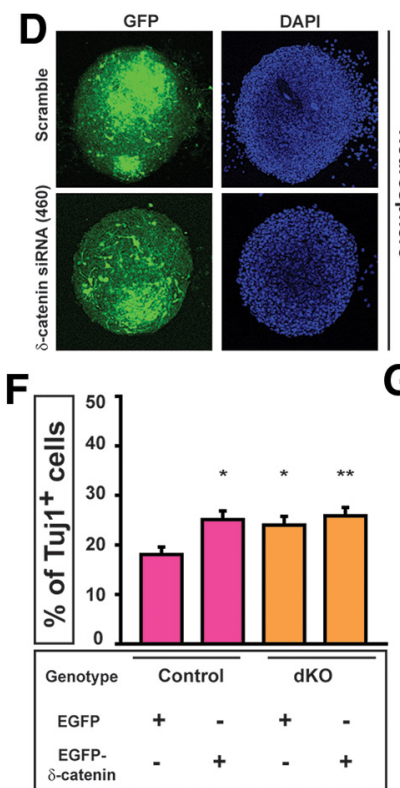

G
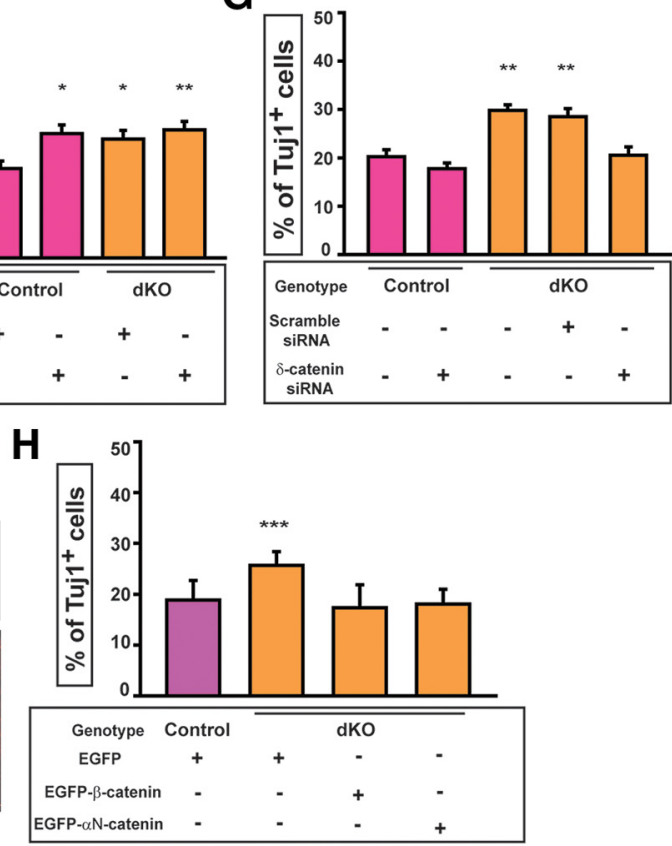

Figure 5. 14-3-3 regulates actin dynamics through the Rho family of GTPases/Limk1/cofilin signaling pathway. $\boldsymbol{A}$, Rho-GTPases' activity assay in neuronal progenitor cells. ${ }^{* *} p<0.01 .{ }^{* * *} p<$ 0.001. B, Immunoblot analysis of Limk1/phosphorylated Limk1 and cofilin/phosphorylated cofilin in neuronal progenitor cells. Right graphs, Quantification of the relative expression of Limk1, phosphorylated Limk1, cofilin, and phosphorylated cofilin. ${ }^{*} p<0.05 .{ }^{* * *} p<0.001$. C, Immunohistochemistry with anti-F-actin antibody on the dK0 mice. Scale bar, $100 \mu$ m. D, GFP expression by lentivirus in neuronal progenitor cells. Two representative neurospheres transformed with lentiviruses are shown. Top, Lentivirus coding GFP-Scramble. Bottom, Lentiviruses coding GFP- $\delta$ -

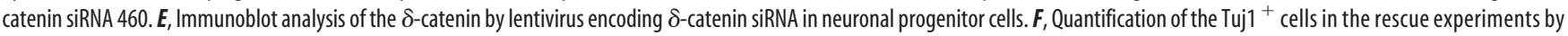
overexpression of $\delta$-catenin in the in vitro neuronal differentiation assay. $n=14$ areas from three animals per genotype. ${ }^{*} p<0.05$. ${ }^{* *} p<0.01$. $\mathbf{G}, 0$ uantification of the Tuj $1{ }^{+}$cells in the rescue experiments by knockdown of $\delta$-catenin proteins by siRNA in the in vitro neuronal differentiation assay. $n=8-14$ areas from two to four animals per genotype. ${ }^{* *} p<0.01$. $\boldsymbol{H}$, Quantification of the Tuj ${ }^{+}$cells in the rescue experiments by overexpression of $\beta$-catenin and $\alpha \mathrm{N}$-catenin in the in vitro neuronal differentiation assay. $n=14$ areas from three animals per genotype. ${ }^{* *} p<0.001$.

plete dKO mice (Ywhae flox/flox; Ywhaz ${ }^{\mathrm{KO} / \mathrm{KO}} ;$ hGFAP-Cre ${ }^{+}$). We detected increased expression of $\delta$-catenin in both types of $\mathrm{dKO}$ mice, whereas $\beta$-catenin and $\alpha \mathrm{N}$-catenin expression was decreased (Fig. 4A).

Next, we tested whether the deficiency of $14-3-3 \varepsilon / \zeta$ resulted in changes in the distribution of $\delta$-catenin in the VZ (Fig. $4 B$ ). There were no significant changes in the distribution of $\delta$-catenin in the $\mathrm{VZ}$ in single-mutant mice. However, we found a diffuse distribution of $\delta$-catenin in the $\mathrm{dKO}$ mice compared with the wild-type control mice, where the $\delta$-catenin strongly localized to the apical surface of the VZ (Fig. $4 B$, arrows).

To clarify the mechanism by which the deficiency of $14-3-3 \varepsilon / \zeta$ caused increased expression of $\delta$-catenin, we tested whether the 14-3-3 proteins regulated the stability of $\delta$-catenin. Transfected HEK-293T cells were treated with cycloheximide to inhibit protein synthesis. The expression of both 14-3-3 proteins accelerated the turnover of $\delta$-catenin (Fig. $4 C$ ). Next, we tested whether this increased turnover was mediated by ubiquitin proteolysis. Treatment with the ubiquitin inhibitor, MG132, rescued the accelerated $\delta$-catenin turnover caused by expression of 14-3-3 (Fig. 4D), suggesting that the $\delta$-catenin degradation from binding these 14-3-3 proteins is mediated by ubiquitin proteolysis. To test this hypothesis, we performed a direct ubiquitination assay by overexpressing HA-tagged ubiquitin (Fig. 4E). Although the $\delta$-catenin proteins were ubiquitinated without overexpression of the 14-3-3 proteins, overexpression of the 14-3-3 proteins caused the accelerated ubiquitination of the $\delta$-catenin proteins. Finally, loss of Ywhae and Ywhaz in neural progenitor cells resulted in $\delta$-catenin stabilization (Fig. $4 F$ ). Thus, the $14-3-3$ proteins control $\delta$-catenin stability through the ubiquitin proteolysis system in neural progenitor cells.

Increased $\delta$-catenin expression by 14-3-3 deficiency resulted in abnormal activity of the Rho family of GTPases and its downstream effectors

Catenins regulate the activity of RhoA, Racl, and cdc42, and the activation of the Rho family of GTPases results in the phosphorylation of Limk1. Subsequently, phospho-Limk1 phosphorylates cofilin, resulting in an inactive form that is unable to sever F-actin. Therefore, F-actin formation is accelerated (Luo, 2002). 

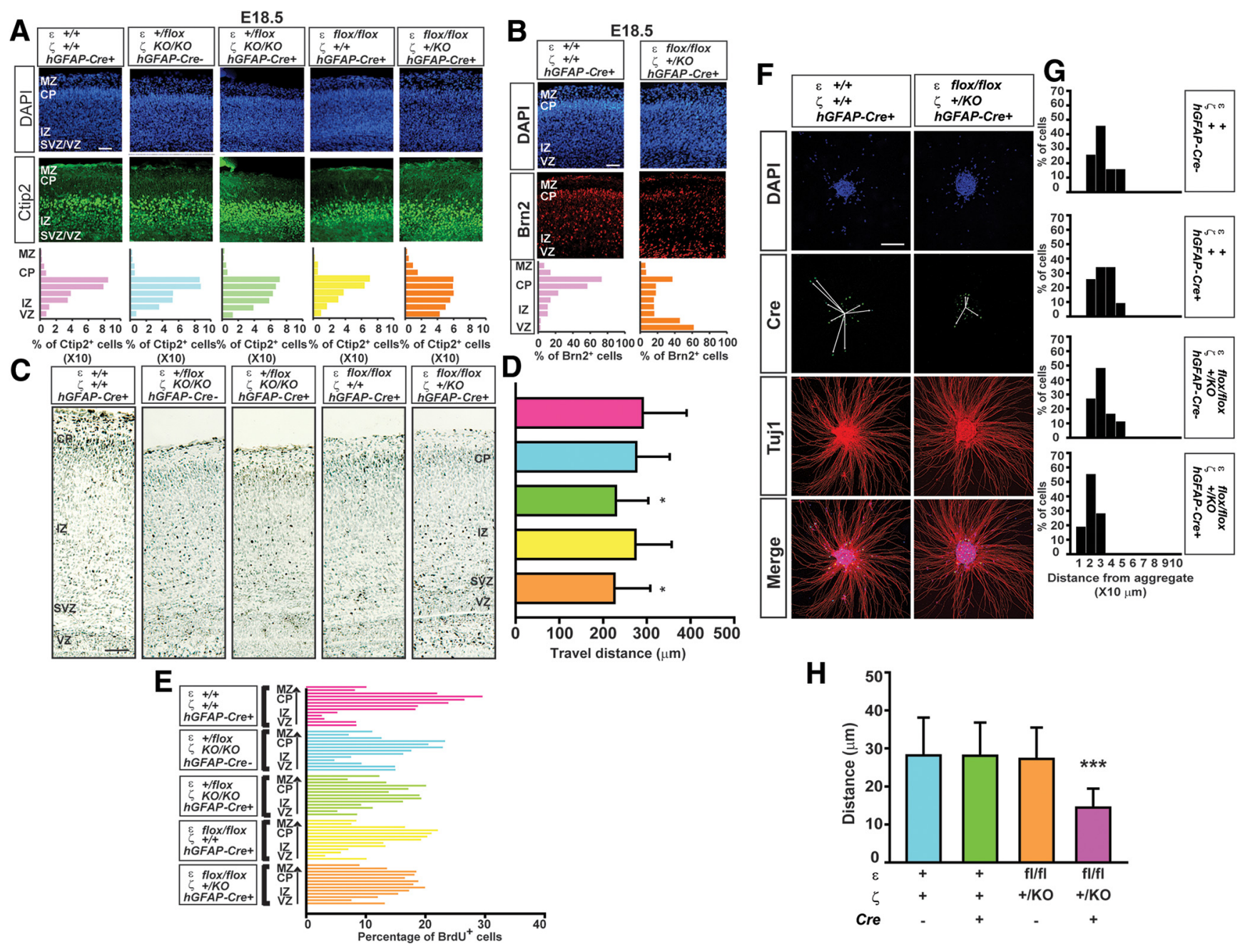

Figure 6. 14-3-3 deficiency caused neuronal migration defects. $A$, Immunohistochemistry with anti-Ctip2 antibody on the dK0 mice at E18.5 and quantification of the Ctip2 ${ }^{+}$cells in the cortex. Scale bar, $100 \mu \mathrm{m}$. B, Immunohistochemistry with anti-Brn2 antibody on the dKO mice at E18.5 and quantification of the Brn2 ${ }^{+}$cells in the cortex. Scale bar, $100 \mu \mathrm{m}$. C, BrdU birthdating analysis. BrdU was injected into dams atE15.5, and then embryos were collected at E18.5. Brains were sectioned and stained with anti-BrdU antibody. Scale bar, $50 \mu \mathrm{m}$. D, Quantification of the travel distance of $\mathrm{BrdU}^{+}$neurons from VZ. ${ }^{*} p<0.05 . n=25-27$ cells from three to five animals per genotype. $E$, Quantification of the distribution of the BrdU ${ }^{+}$cells through the cortex. Arrows indicate the migration direction. $\boldsymbol{F}$, In vitro neuronal migration assay by using cerebellar granule cells. Arrows indicate the migration direction of the granule cells from the center of aggregates. $S c a l e$ bar, 100 $\mu \mathrm{m} . \boldsymbol{G}$, Quantification of the distribution of the granule cells from the center of aggregates. $\boldsymbol{H}$, Quantification of the travel distance of the granule cells from the center of aggregates. ${ }^{* * *} p<0.001$. $n=11-20$ cells from three or four animals per genotype.

To test whether this pathway is involved in the $\mathrm{dKO}$ mutants that have increased levels of $\delta$-catenin, we analyzed whether the deficiency of $14-3-3 \varepsilon / \zeta$ affected Rho GTPases' activity in neural progenitor cells. The partial (lane 2 and 3 from left in each panel) and complete (right lane in each panel) dKO 14-3-3-deficient neurospheres displayed decreased activity of RhoA, Racl, and cdc42 compared with the wild-type control neurospheres (left lane in each panel) (Fig. 5A). Next, we performed Western blot analysis to analyze the expression and phosphorylation status of the downstream molecules. There was no difference in Limk1 and cofilin levels among the wild-type control, the partial $\mathrm{dKO}$, and the complete $\mathrm{dKO}$ neuronal progenitor cells (Fig. 5B). However, the phosphorylation of both of these proteins was decreased in the partial and complete dKO neural progenitor cells (Fig. 5B). The unphosphorylated form of cofilin is active and severs F-actin. Therefore, we examined whether the dKO mice displayed decreased $\mathrm{F}$-actin staining in vivo and found that $\mathrm{F}$-actin was decreased in the dKO mouse brain (Fig. $5 C$ ). Thus, increased expression of $\delta$-catenin resulted in the inactivation of the Rho family GTPases followed by decreased phosphorylation of Limk1 and cofilin proteins, resulting in a reduction of F-actin.

We tested whether the phenotypes seen in the 14-3-3 dKO neuronal progenitor cells were mediated by $\delta$-catenin. We produced lentiviruses encoding EGFP alone or EGFP-tagged $\delta$-catenin and scramble siRNA or $\delta$-catenin-specific siRNA. The infection of lentivirus coding scrambled siRNA and $\delta$-catenin siRNA was effective in transducing most of the neural progenitors in a neurosphere, and $\delta$-catenin siRNA was effective in knocking down the expression of $\delta$-catenin in neuronal progenitor cells (Fig. $5 D, E$ ). Overexpression of EGFP- $\delta$-catenin in wild-type neurospheres resulted in the increased differentiation of neuronal progenitor cells into neurons (Fig. $5 F$ ), mimicking the phenotype seen in the dKO cells. Importantly, knockdown of $\delta$-catenin by a specific siRNA, but not scramble siRNA, normalized the neuronal differentiation in the dKO cells (Fig. 5G). Finally, as the expression of the $\beta$-catenin and the $\alpha \mathrm{N}$-catenin proteins was decreased in neural progenitor cells from the $\mathrm{dKO}$ mice (Fig. 4A), we tested whether the overexpression of these 
A
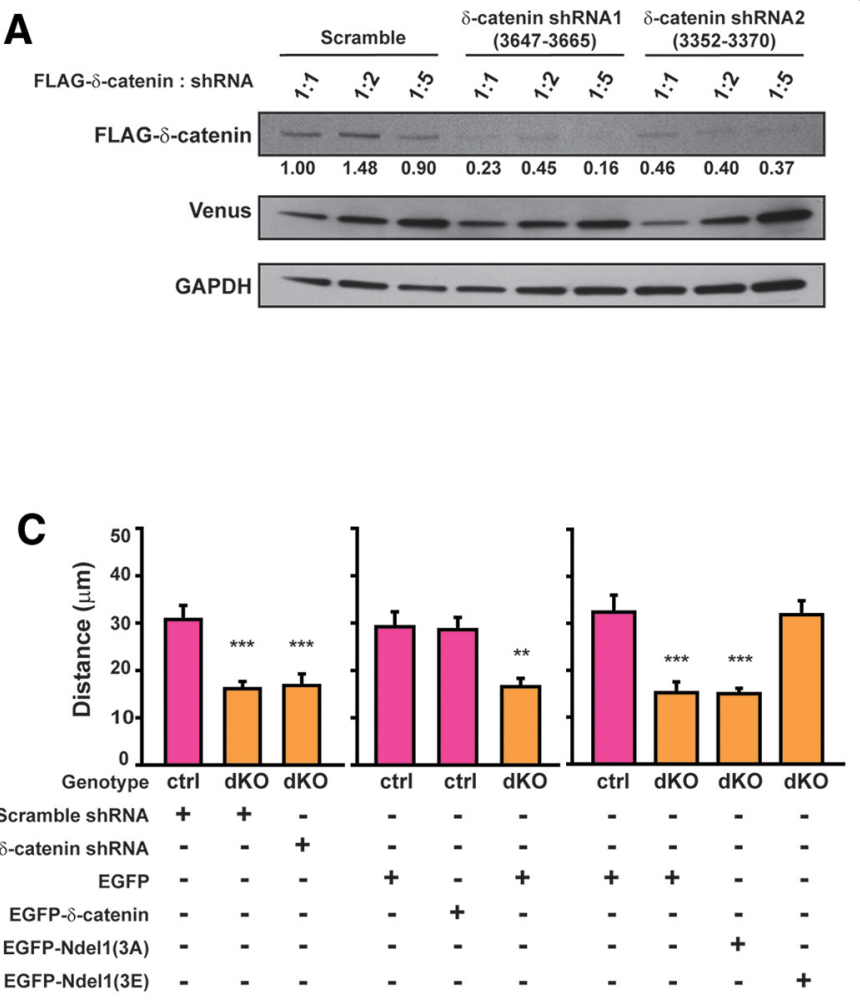

B
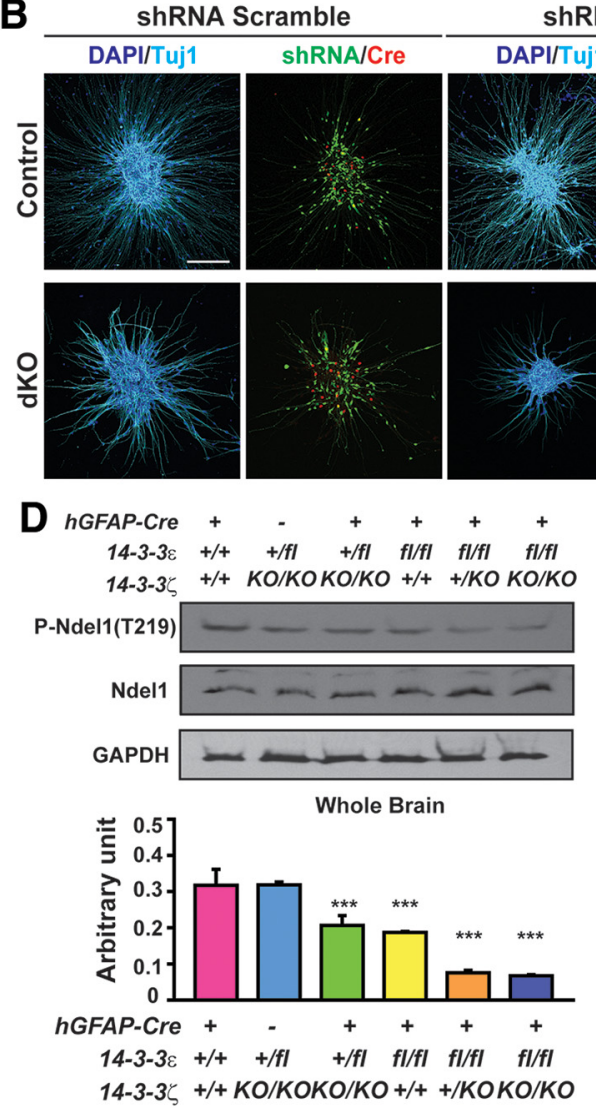

ShRNA $\delta$-catenin
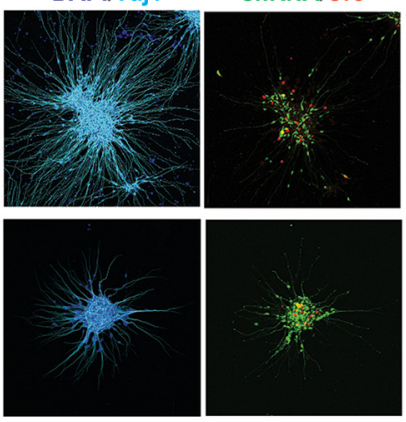

E

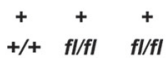
$+/++/ K O K O / K O$
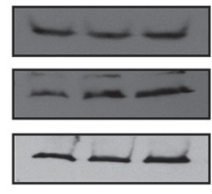

Neurosphere

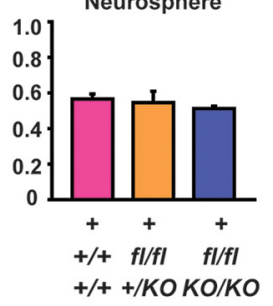

Figure 7. Neuronal migration defects seen in the dKO mice are mediated by Ndel1, but not $\delta$-catenin. $\boldsymbol{A}$, Immunoblot analysis of the $\delta$-catenin by shRNA plasmid transfection. $\boldsymbol{B}$, Representative photos from the rescue experiments by knockdown of $\delta$-catenin proteins by shRNA in the neuronal migration assay. Scale bar, $100 \mu \mathrm{m}$. C, Quantification of the average travel distance in the neuronal migration assay. $n=8-11$ cells from three animals per genotype. ${ }^{* *} p<0.01 .{ }^{* *} p<0.001$. ctrl: control. $\boldsymbol{D}$, Immunoblot analysis of the expression of the phosphorylated Ndel1 proteins in the cerebral cortex at E16.5. Bottom, Quantification of the relative expression of the phosphorylated Ndel1 proteins. ${ }^{* * *} p<0.001 . E$, Immunoblot analysis of the expression of the phosphorylated Ndel1 proteins in neural progenitor cells. Bottom, Quantification of the relative expression of the phosphorylated Ndel1 proteins.

proteins normalized the increased neuronal differentiation seen in the dKO mice (Fig. $5 \mathrm{H}$ ). Overexpression of EGFP- $\beta$-catenin and EGFP- $\alpha \mathrm{N}$-catenin in the $\mathrm{dKO}$ neurospheres normalized the neuronal differentiation into neurons, indicating that, in addition to $\delta$-catenin, the $\beta$-catenin and the $\alpha \mathrm{N}$-catenin proteins play an important role in the 14-3-3-mediated neuronal differentiation into neurons. These results demonstrate that the neural differentiation phenotype found in the $\mathrm{dKO}$ mice result from increased expression of $\delta$-catenin associated with the decreased expression of the $\beta$-catenin and $\alpha \mathrm{N}$-catenin proteins.

\section{4-3-3 deficiency resulted in neuronal migration defects in} the cortex

To determine whether the $\mathrm{dKO}$ mice displayed neuronal migration defects in the cortex, we used two different cell layer markers, Ctip2 and the Brn2. Ctip2-positive cells were predominantly localized in layer 4 in control (wild-type and single mutant) mice, whereas in $\mathrm{dKO}$ mice, Ctip2-positive cells were diffusely distributed in the cortex, especially in the deeper layers, including the VZ (Fig. 6A). Brn2 was predominantly expressed in layer 2 to layer 4 in control mice (Fig. $6 B$ ), whereas in $\mathrm{dKO}$ mice, Brn2-positive cells were diffusely distributed in the cortex, especially in the deeper layers (Fig. 6B). These data strongly suggest that the $\mathrm{dKO}$ mice display neuronal migration defects in the cortex.

To test this hypothesis, we used BrdU birthdating analysis. BrdU-positive cells were accumulated predominantly in the $\mathrm{CP}$ region in control wild-type mice. In the $\mathrm{dKO}$ mutant mice, the BrdU-positive cells were broadly localized in the cortex and the average travel distance was decreased (Fig. 6C-E), whereas the single mutants displayed an intermediate phenotype.

To confirm that this phenotype is the result of defective neuronal migration, we used an in vitro neural migration assay. The $\mathrm{dKO}$ cells migrated shorter distances than wild-type control cells (Fig. $6 F-H$ ), consistent with the data from the BrdU birthdating analysis. These data demonstrate that the 14-3-3 proteins are important for the migration of postmitotic neurons.

Next, we tested whether the neuronal migration defects caused by the deficiency of $14-3-3 \varepsilon / \zeta$ were rescued by knockdown of $\delta$-catenin expression. First, we tested the efficiency of the $\delta$-catenin shRNA vectors (Fig. $7 A$ ). We confirmed that the expression of the $\delta$-catenin proteins was efficiently suppressed by either shRNA1 or shRNA2 (Fig. 7A). Despite efficient gene silencing, knockdown of $\delta$-catenin by shRNA1 did not rescue neuronal migration defects caused by 14-3-3 deficiency (Fig. $7 B, C$, left), suggesting that $\delta$-catenin is not important for the migration of the postmitotic neurons. To confirm this hypothesis, we tested whether $\delta$-catenin overexpression affected neuronal migration, and there was no effect in vitro (Fig. $7 C$, middle).

Previously, we found that the 14-3-3 proteins bind to phosphorylated Ndel1 proteins, and Ndel1 is important for neuronal migration in the cortex (Toyo-oka et al., 2003, 2005). Therefore, we tested whether the phosphorylation mutants of Ndell were able to rescue the neural migration defects in the $\mathrm{dKO}$ mutants 


\section{A WT cells}

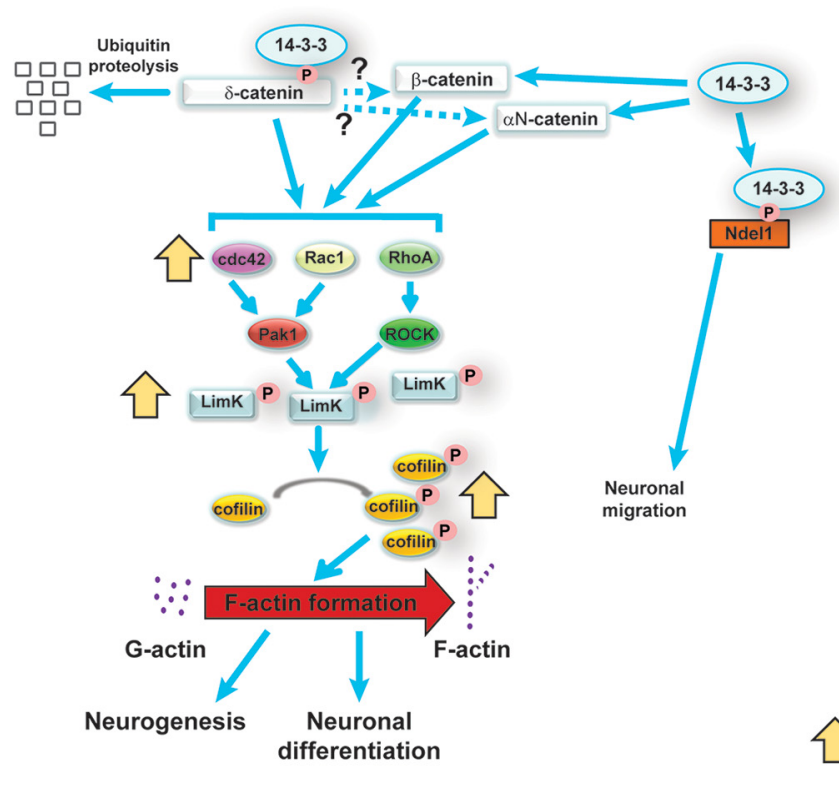

B 14-3-3 deficient cells

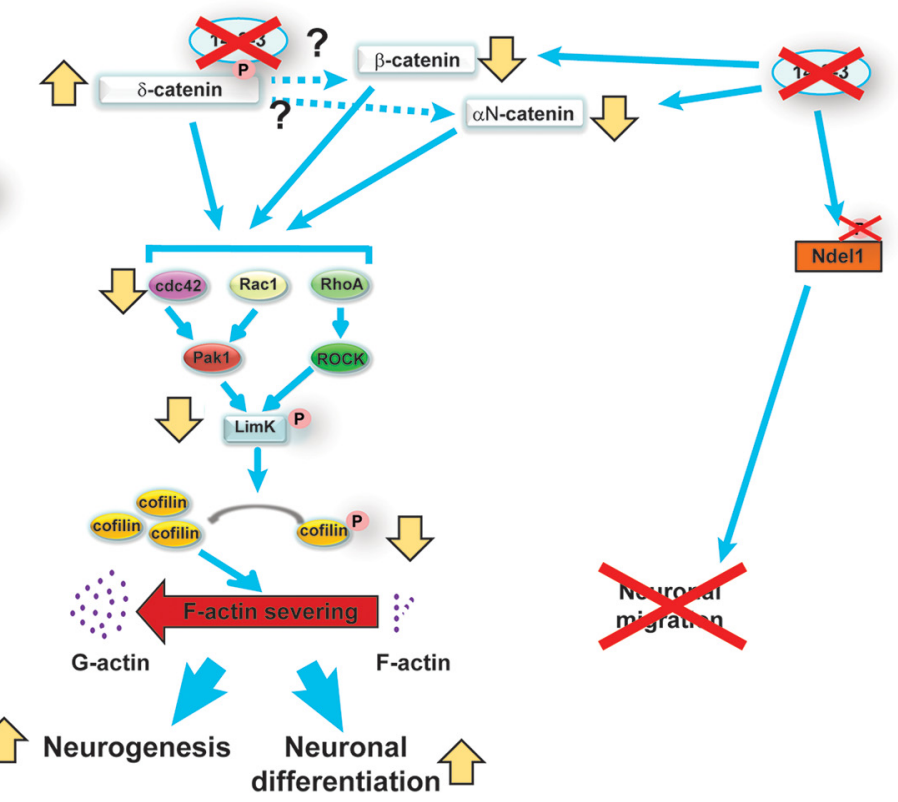

Apoptosis

Figure 8. Schematic model of 14-3-3 protein functions in developing cerebral cortex. In wild-type progenitor cells (A), 14-3-3 proteins interact with $\delta$-catenin and regulate its stability through the ubiquitin proteolysis system. $\delta$-catenin proteins may regulate the stability of $\beta$-catenin and $\alpha \mathrm{N}$-catenin proteins (dotted lines). Catenins activate the Rho family of GTPases that include RhoA, Rac1, and cdc42, and these proteins cause the phosphorylation of Limk1 protein through Pak and ROCK proteins. Then, phospho-Limk1 proteins phosphorylate cofilin. Finally, F-actin formation is

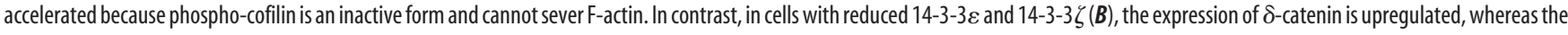
expression of $\beta$-catenin and $\alpha \mathrm{N}$-catenin is downregulated. This results in the inactivation of the Rho family of GTPases, followed by decreased phosphorylation of the Limk1 and cofilin proteins. Then, the accumulation of the unphosphorylated active cofilins causes the acceleration of $G$-actin formation. Finally, this results in the increase of neurogenesis and neuronal differentiation followed by apoptosis as well as the defect in neuronal migration.

(Fig. 7C, right). The phosphomimetic (triple substitution of $\mathrm{E}$ for $\mathrm{S} / \mathrm{T})$ Ndell mutant was able to rescue the neuronal migration defects in the $\mathrm{dKO}$ mice, but the phospho-inactive (A for S/T) mutant did not (Fig. 7C, right). Also, we previously found that binding of the $14-3-3 \varepsilon$ proteins to the phosphorylated Ndell proteins protects the phosphorylated Ndell proteins from the dephosphorylation by the PP2A phosphatase proteins (Toyo-oka et al., 2003). Therefore, we tested the phosphorylation status of the Ndell proteins in the entire brain and the neural progenitor cells. The dKO mice brain displayed decreased phosphorylated Ndel1 proteins (Fig. 7D). However, there was no significant difference in the amount of phospho-Ndel1 between the neural progenitor cells from $\mathrm{dKO}$ and control mice (Fig. 7E).

Together, these data implicate distinct pathways mediated by the binding of 14-3-3 proteins in the regulation of neurogenesis and neuronal migration. The neurogenesis defects displayed by 14-3-3 dKO mice result from the role of these 14-3-3 proteins in binding $\delta$-catenin, regulating the expression levels of $\delta$-catenin, $\beta$-catenin, and $\alpha \mathrm{N}$-catenin, and regulating F-actin via the regulation of the Rho family of GTPases, LimK1 and cofilin. By contrast, the neuronal migration defects result from the role of these 14-3-3 proteins in the binding of Ndel1.

\section{Discussion}

We have discovered that the combined deficiency of both Ywhae and Ywhaz resulted in severe phenotypes during embryogenesis, and conditional double mutants $(\mathrm{dKO})$ displayed seizures. The $\mathrm{dKO}$ mutants displayed novel and severe defects during neuro- genesis and neuronal migration, and some of these defects were only found in $\mathrm{dKO}$ mice, demonstrating an important level of redundancy between $14-3-3 \varepsilon$ and $14-3-3 \zeta$ proteins. $14-3-3 \varepsilon$ and 14-3-3 $\zeta$ together participate in the regulation of proliferation and differentiation of neural progenitor cells in the cerebral cortex by binding to and controlling the stability of $\delta$-catenin and the expression levels of $\beta$-catenin and $\alpha \mathrm{N}$-catenin. Surprisingly, $\delta$-catenin was not involved in the severe neuronal migration phenotypes displayed by the dKO mutants, but instead those phenotypes appear to involve Ndel1, a previously identified binding partner for 14-3-3e (Toyo-oka et al., 2003). Thus, $14-3-3 \varepsilon$ and $14-3-3 \zeta$ together participate in critical signal transduction pathways important in distinct processes during cortical development.

We discovered that loss of these 14-3-3 proteins resulted in stabilization of $\delta$-catenin, decreased expression of $\beta$-catenin and $\alpha \mathrm{N}$-catenin, inactivation of the Rho family GTPases, and decreased phosphorylated forms of Limk1 and cofilin. Previous studies indicated that the 14-3-3 proteins bind to Limk1, cofilin and slingshot (SSH) phosphatase (Gohla and Bokoch, 2002; Birkenfeld et al., 2003; Soosairajah et al., 2005). Therefore, we cannot exclude the possibilities that the 14-3-3 proteins regulate F-actin formation via many proteins directly and/or indirectly. However, our rescue experiments revealed that knockdown of the overexpressed $\delta$-catenin proteins or overexpression of $\beta$-catenin and $\alpha \mathrm{N}$-catenin normalized the increased differentiation phenotype of progenitor cells into 
neurons in $\mathrm{dKO}$ neural progenitor cells. Thus, these data indicate that catenin proteins are key players of the neuronal differentiation mediated by 14-3-3 proteins.

A previous study reported that the overexpression of the $\delta$-catenin proteins decreased RhoA activity but not the activity of Rac1 and Cdc42 in MEF cells (Kim et al., 2008). Alternatively, Abu-Elneel et al. (2008) demonstrated that Rac and Cdc42 activity was dramatically increased by $\delta$-catenin overexpression in Chinese hamster ovary cells. However, here we demonstrate that the loss of 14-3-3 proteins resulted in stabilization of $\delta$-catenin and the inactivation of RhoA, Racl, and cdc42 in neuronal progenitor cells (Fig. 5A). These conflicting results may be explained by cell type differences used in each study.

In addition to increased levels of $\delta$-catenin, the $\mathrm{dKO}$ neural progenitor cells displayed decreased expression of $\beta$-catenin and $\alpha \mathrm{N}$-catenin (Fig. 4A), and overexpression of $\beta$-catenin and $\alpha \mathrm{N}$ catenin in neuronal progenitor cells prepared from the $\mathrm{dKO}$ mice normalized the defects in neuronal differentiation into neurons (Fig $5 \mathrm{H}$ ). A previous study indicated that overexpression of $\delta$-catenin stimulated $\beta$-catenin turnover via ubiquitin-mediated proteolysis (Bareiss et al., 2010). Therefore, we hypothesize that the same mechanism may be working to regulate both $\beta$-catenin and $\alpha \mathrm{N}$-catenin. Previous reports indicated that $\beta$-catenin negatively regulated the number of IPCs (Mutch et al., 2010). This is consistent with our findings of decreased expression of the $\beta$-catenin proteins in neural progenitor cells (Fig. 4A).

We found that the 14-3-3 proteins bind to the PKAphosphorylated Ser1094 of the $\delta$-catenin by producing the various serine/threonine to alanine mutants (Fig. $3 D-K$ ). In addition to Ser1094, the Ser357 to alanine mutation caused decreased binding between the 14-3-3 proteins and $\delta$-catenin. Ser357 is phosphorylated by Cdk5 (Poore et al., 2010). Therefore, this phosphorylation may be important for sequential phosphorylation of the Ser 1094 by PKA by regulating specific conformational change.

We demonstrated that the $\mathrm{dKO}$ mice occasionally died after 2 months and displayed severe seizures (Fig. $1 \mathrm{H}, \mathrm{I}$ ), providing the first direct evidence for the involvement of 14-3-3 proteins in the onset of epilepsy. Interestingly, neurogenesis and neuronal migration defects are often associated with epilepsy (Schwartzkroin and Walsh, 2000; Ayala et al., 2007). For example, mutation and/or deletion of the Lis1 or Dcx genes results in severe epilepsy (Greenwood et al., 2009; Lapray et al., 2010). Our data provide further support that genes important for neurogenesis and neuronal migration are also important for the onset of epilepsy.

In conclusion, we uncovered a novel function of the 14-3-3e and $14-3-3 \zeta$ in neurogenesis, proliferation, and differentiation of neural progenitor cells in the cerebral cortex (Fig. 8). These 143-3 proteins accelerate the turnover of the $\delta$-catenin through the ubiquitin proteolysis system by interacting with phosphorylated $\delta$-catenin in wild-type neural progenitor cells. In cells with reduced $14-3-3 \varepsilon$ and $14-3-3 \zeta$, the expression of $\delta$-catenin is upregulated in association with the downregulation of $\beta$-catenin and $\alpha \mathrm{N}$-catenin, resulting in the inactivation of the Rho family of GTPases that include cdc42, Rac1, and RhoA, followed by the decreased phosphorylation of the Limk1 and cofilin proteins. Finally, the accumulation of the unphosphorylated active cofilins results in F-actin severing. Thus, $14-3-3 \varepsilon$ and $14-3-3 \zeta$ play important roles in proliferation and differentiation of neural progenitor cells through the $\delta$-catenin/Limk-1/cofilin/actin signaling pathway. Furthermore, Ndel1 proteins, but not $\delta$-catenin, play important roles in neuronal migration mediated by the same 14-3-3 proteins.

\section{References}

Abu-Elneel K, Ochiishi T, Medina M, Remedi M, Gastaldi L, Caceres A, Kosik KS (2008) A $\delta$-catenin signaling pathway leading to dendritic protrusions. J Biol Chem 283:32781-32791. CrossRef Medline

Arikkath J, Israely I, Tao Y, Mei L, Liu X, Reichardt LF (2008) Erbin controls dendritic morphogenesis by regulating localization of $\delta$-catenin. J Neurosci 28:7047-7056. CrossRef Medline

Arikkath J, Peng IF, Ng YG, Israely I, Liu X, Ullian EM, Reichardt LF (2009) Delta-catenin regulates spine and synapse morphogenesis and function in hippocampal neurons during development. J Neurosci 29:5435-5442. CrossRef Medline

Ayala R, Shu T, Tsai LH (2007) Trekking across the brain: the journey of neuronal migration. Cell 128:29-43. CrossRef Medline

Bareiss S, Kim K, Lu Q (2010) Delta-catenin/NPRAP: a new member of the glycogen synthase kinase-3beta signaling complex that promotes betacatenin turnover in neurons. J Neurosci Res 88:2350-2363. CrossRef Medline

Birkenfeld J, Betz H, Roth D (2003) Identification of cofilin and LIMdomain-containing protein kinase 1 as novel interaction partners of 143-3 zeta. Biochem J 369:45-54. CrossRef Medline

Bridges D, Moorhead GB (2005) 14-3-3 proteins: a number of functions for a numbered protein. Sci STKE 2005:re10. Medline

Broadie K, Rushton E, Skoulakis EM, Davis RL (1997) Leonardo, a Drosophila 14-3-3 protein involved in learning, regulates presynaptic function. Neuron 19:391-402. CrossRef Medline

Cheah PS, Ramshaw HS, Thomas PQ, Toyo-Oka K, Xu X, Martin S, Coyle P, Guthridge MA, Stomski F, van den Buuse M, Wynshaw-Boris A, Lopez AF, Schwarz QP (2011) Neurodevelopmental and neuropsychiatric behaviour defects arise from 14-3-3zeta deficiency. Mol Psychiatry 17:451466. CrossRef Medline

Chen S, Synowsky S, Tinti M, MacKintosh C (2011) The capture of phosphoproteins by 14-3-3 proteins mediates actions of insulin. Trends Endocrinol Metab 22:429-436. CrossRef Medline

Engele J, Bohn MC (1992) Effects of acidic and basic fibroblast growth factors (aFGF, bFGF) on glial precursor cell proliferation: age dependency and brain region specificity. Dev Biol 152:363-372. CrossRef Medline

Fish JL, Kosodo Y, Enard W, Pääbo S, Huttner WB (2006) Aspm specifically maintains symmetric proliferative divisions of neuroepithelial cells. Proc Natl Acad Sci U S A 103:10438-10443. CrossRef Medline

Gardino AK, Yaffe MB (2011) 14-3-3 proteins as signaling integration points for cell cycle control and apoptosis. Semin Cell Dev Biol 22:688695. CrossRef Medline

Gohla A, Bokoch GM (2002) 14-3-3 regulates actin dynamics by stabilizing phosphorylated cofilin. Curr Biol 12:1704-1710. CrossRef Medline

Greenwood JS, Wang Y, Estrada RC, Ackerman L, Ohara PT, Baraban SC (2009) Seizures, enhanced excitation, and increased vesicle number in Lis1 mutant mice. Ann Neurol 66:644-653. CrossRef Medline

Hand R, Polleux F (2011) Neurogenin2 regulates the initial axon guidance of cortical pyramidal neurons projecting medially to the corpus callosum. Neural Dev 6:30. CrossRef Medline

Ikeda M, Hikita T, Taya S, Uraguchi-Asaki J, Toyo-oka K, Wynshaw-Boris A, Ujike H, Inada T, Takao K, Miyakawa T, Ozaki N, Kaibuchi K, Iwata N (2008) Identification of YWHAE, a gene encoding 14-3-3epsilon, as a possible susceptibility gene for schizophrenia. Hum Mol Genet 17:32123222. CrossRef Medline

Israely I, Costa RM, Xie CW, Silva AJ, Kosik KS, Liu X (2004) Deletion of the neuron-specific protein $\delta$-catenin leads to severe cognitive and synaptic dysfunction. Curr Biol 14:1657-1663. CrossRef Medline

Kamitani T, Kito K, Nguyen HP, Yeh ET (1997) Characterization of NEDD8, a developmentally down-regulated ubiquitin-like protein. J Biol Chem 272:28557-28562. CrossRef Medline

Kim H, Han JR, Park J, Oh M, James SE, Chang S, Lu Q, Lee KY, Ki H, Song WJ, Kim K (2008) Delta-catenin-induced dendritic morphogenesis: an essential role of p190RhoGEF interaction through Akt1-mediated phosphorylation. J Biol Chem 283:977-987. CrossRef Medline

Kitajima H, Yoshimura S, Kokuzawa J, Kato M, Iwama T, Motohashi T, Kunisada T, Sakai N (2005) Culture method for the induction of neurospheres from mouse embryonic stem cells by coculture with PA6 stromal cells. J Neurosci Res 80:467-474. CrossRef Medline

Kosaka Y, Cieslik KA, Li L, Lezin G, Maguire CT, Saijoh Y, Toyo-oka K, Gambello MJ, Vatta M, Wynshaw-Boris A, Baldini A, Yost HJ, Brunelli L (2012) $14-3-3 \varepsilon$ plays a role in cardiac ventricular compaction by regulat- 
ing the cardiomyocyte cell cycle. Mol Cell Biol 32:5089-5102. CrossRef Medline

Kriegstein A, Alvarez-Buylla A (2009) The glial nature of embryonic and adult neural stem cells. Annu Rev Neurosci 32:149-184. CrossRef Medline

Lapray D, Popova IY, Kindler J, Jorquera I, Becq H, Manent JB, Luhmann HJ, Represa A (2010) Spontaneous epileptic manifestations in a DCX knockdown model of human double cortex. Cereb Cortex 20:2694-2701. CrossRef Medline

Luo L (2002) Actin cytoskeleton regulation in neuronal morphogenesis and structural plasticity. Annu Rev Cell Dev Biol 18:601-635. CrossRef Medline

Luu HH, Zhou L, Haydon RC, Deyrup AT, Montag AG, Huo D, Heck R, Heizmann CW, Peabody TD, Simon MA, He TC (2005) Increased expression of S100A6 is associated with decreased metastasis and inhibition of cell migration and anchorage independent growth in human osteosarcoma. Cancer Lett 229:135-148. CrossRef Medline

Mackie S, Aitken A (2005) Novel brain 14-3-3 interacting proteins involved in neurodegenerative disease. FEBS J 272:4202-4210. CrossRef Medline

Miller MW, Nowakowski RS (1988) Use of bromodeoxyuridineimmunohistochemistry to examine the proliferation, migration and time of origin of cells in the central nervous system. Brain Res 457:44-52. CrossRef Medline

Mutch CA, Schulte JD, Olson E, Chenn A (2010) Beta-catenin signaling negatively regulates intermediate progenitor population numbers in the developing cortex. PLoS One 5:e12376. CrossRef Medline

Nakagawa M, Fukata M, Yamaga M, Itoh N, Kaibuchi K (2001) Recruitment and activation of Racl by the formation of E-cadherin-mediated cell-cell adhesion sites. J Cell Sci 114:1829-1838. Medline

Pontious A, Kowalczyk T, Englund C, Hevner RF (2008) Role of intermediate progenitor cells in cerebral cortex development. Dev Neurosci 30:2432. CrossRef Medline

Poore CP, Sundaram JR, Pareek TK, Fu A, Amin N, Mohamed NE, Zheng YL, Goh AX, Lai MK, Ip NY, Pant HC, Kesavapany S (2010) Cdk5-mediated phosphorylation of $\delta$-catenin regulates its localization and GluR2mediated synaptic activity. J Neurosci 30:8457-8467. CrossRef Medline

Racine R, Burnham WM, Livingston K (1979) The effect of procaine hydrochloride and diazepam, separately or in combination, on corticogeneralized kindled seizures. Electroencephalogr Clin Neurophysiol 47: 204-212. CrossRef Medline

Rasband WS (1997-2014) ImageJ. Bethesda, MD: National Institutes of Health.

Sanada K, Tsai LH (2005) G protein $\beta \gamma$ subunits and AGS3 control spindle orientation and asymmetric cell fate of cerebral cortical progenitors. Cell 122:119-131. CrossRef Medline

Schwartzkroin PA, Walsh CA (2000) Cortical malformations and epilepsy. Ment Retard Dev Disabil Res Rev 6:268-280. CrossRef Medline

Soosairajah J, Maiti S, Wiggan O, Sarmiere P, Moussi N, Sarcevic B, Sampath R, Bamburg JR, Bernard O (2005) Interplay between components of a novel LIM kinase-slingshot phosphatase complex regulates cofilin. EMBO J 24:473-486. CrossRef Medline

Soriano E, Del Rio JA (1991) Simultaneous immunocytochemical visualization of bromodeoxyuridine and neural tissue antigens. J Histochem Cytochem 39:255-263. CrossRef Medline

Soriano P (1999) Generalized lacZ expression with the ROSA26 Cre reporter strain. Nat Genet 21:70-71. CrossRef Medline

Tanaka T, Serneo FF, Higgins C, Gambello MJ, Wynshaw-Boris A, Gleeson JG (2004) Lis1 and doublecortin function with dynein to mediate coupling of the nucleus to the centrosome in neuronal migration. J Cell Biol 165:709-721. CrossRef Medline

Toyo-oka K, Shionoya A, Gambello MJ, Cardoso C, Leventer R, Ward HL, Ayala R, Tsai LH, Dobyns W, Ledbetter D, Hirotsune S, Wynshaw-Boris A (2003) 14-3-3epsilon is important for neuronal migration by binding to NUDEL: a molecular explanation for Miller-Dieker syndrome. Nat Genet 34:274-285. CrossRef Medline

Toyo-Oka K, Sasaki S, Yano Y, Mori D, Kobayashi T, Toyoshima YY, Tokuoka SM, Ishii S, Shimizu T, Muramatsu M, Hiraiwa N, Yoshiki A, Wynshaw-Boris A, Hirotsune S (2005) Recruitment of katanin p60 by phosphorylated NDEL1, an LIS1 interacting protein, is essential for mitotic cell division and neuronal migration. Hum Mol Genet 14:31133128. CrossRef Medline

Tzivion G, Avruch J (2002) 14-3-3 proteins: active cofactors in cellular regulation by serine/threonine phosphorylation. J Biol Chem 277:30613064. CrossRef Medline

Warming S, Costantino N, Court DL, Jenkins NA, Copeland NG (2005) Simple and highly efficient BAC recombineering using galK selection. Nucleic Acids Res 33:e36. CrossRef Medline

Ying QL, Smith AG (2003) Defined conditions for neural commitment and differentiation. Methods Enzymol 365:327-341. CrossRef Medline

Yingling J, Youn YH, Darling D, Toyo-Oka K, Pramparo T, Hirotsune S, Wynshaw-Boris A (2008) Neuroepithelial stem cell proliferation requires LIS1 for precise spindle orientation and symmetric division. Cell 132:474-486. CrossRef Medline

Youn YH, Pramparo T, Hirotsune S, Wynshaw-Boris A (2009) Distinct dose-dependent cortical neuronal migration and neurite extension defects in Lis1 and Ndel1 mutant mice. J Neurosci 29:15520-15530. CrossRef Medline

Zhong H, Sia GM, Sato TR, Gray NW, Mao T, Khuchua Z, Huganir RL, Svoboda K (2009) Subcellular dynamics of type II PKA in neurons. Neuron 62:363-374. CrossRef Medline

Zhou Y, Schopperle WM, Murrey H, Jaramillo A, Dagan D, Griffith LC, Levitan IB (1999) A dynamically regulated 14-3-3, Slob, and Slowpoke potassium channel complex in Drosophila presynaptic nerve terminals. Neuron 22:809-818. CrossRef Medline

Zhuo L, Theis M, Alvarez-Maya I, Brenner M, Willecke K, Messing A (2001) hGFAP-cre transgenic mice for manipulation of glial and neuronal function in vivo. Genesis 31:85-94. CrossRef Medline 